\title{
Distributional Patterns of Aquatic Empididae (Diptera) along an Elevational Diversity Gradient in a Low Mountain Range: An Example from Central Europe
}

\author{
Iwona Słowińska *(D) and Radomir Jaskuła (D) \\ Department of Invertebrate Zoology and Hydrobiology, Faculty of Biology and Environmental Protection, \\ University of Lodz, Banacha 12/16, 90-237 Łódź, Poland; radomir.jaskula@biol.uni.lodz.pl \\ * Correspondence: iwona.slowinska@biol.uni.lodz.pl
}

Citation: Słowińska, I.; Jaskuła, R. Distributional Patterns of Aquatic Empididae (Diptera) along an

Elevational Diversity Gradient in a Low Mountain Range: An Example from Central Europe. Insects 2021, 12, 165. https://doi.org/10.3390/ insects12020165

Academic Editor: Roberto Pizzolotto

Received: 29 January 2021

Accepted: 10 February 2021

Published: 15 February 2021

Publisher's Note: MDPI stays neutral with regard to jurisdictional claims in published maps and institutional affiliations.

Copyright: (C) 2021 by the authors Licensee MDPI, Basel, Switzerland. This article is an open access article distributed under the terms and conditions of the Creative Commons Attribution (CC BY) license (https:/ / creativecommons.org/licenses/by/ $4.0 /)$.
Simple Summary: The insect distribution and diversity depend on many different abiotic and biotic factors, which is especially well documented in the high mountains but has not been studied in detail in the low mountain massifs. We studied 17 different macro and microhabitat factors that influence the altitudinal distribution of 40 Hemerodromiinae and Clinocerinae species in the Pieniny Mts., Poland. This is the first such study in Central Europe and one of only a few in the world. The results clearly show that species richness and distribution of Hemerodromiinae and Clinocerinae species are changing with the elevational gradient, with a monotonic decline in species richness with increasing elevation observed for the first subfamily and the hump-shaped distribution pattern noted for the second subfamily, as well as the size of the stream/river and the surrounding area in species distribution in the Pieniny Mts.

Abstract: The two subfamilies Hemerodromiinae and Clinocerinae, also known as aquatic dance flies, are a group of small predatory insects occurring mainly in mountainous areas and the northern temperate. However, very little is known about distribution patterns for most of the species. Habitat preferences for 40 aquatic empidid species were analysed in the Pieniny Mts., Poland. Forty-six sampling sites from a major part of this relatively low mountain massif (400-770 m) were chosen, for which 17 micro and macrohabitat environmental variables were measured including both abiotic (altitude, stream mean width and depth, and shading) and biotic factors (13 dominant plant communities). Here we show that numerous studied aquatic Empididae were characterized by unique habitat preferences and were restricted to the foothills or the lower montane zone with only a few species characterized by wider elevational distribution. Chelifera pectinicauda, C. flavella, C. subangusta and Phyllodromia melanocephala (Hemerodromiinae), and Clinocera appendiculata, C. fontinalis, C. wesmaeli, Dolichocephala guttata, D. oblongoguttata, Kowarzia plectrum, Wiedemannia jazdzewskii, and W. thienemanni (Clinocerinae) were clearly associated with the highest altitudes and shaded areas while W. bistigma, W. lamellata, W. phantasma, and W. tricuspidata (Clinocerinae) were clearly associated with the lower elevated, wider stream valleys overgrown by willow brakes. Species richness and diversity decreased along elevational gradient with the hump-shaped diversity pattern noted for the subfamily Clinocerinae. The altitude, size of river/stream as well as the type of plant community were found as the most important factors in the distribution of the studied aquatic empidid species. The present study is the first one focused on elevational diversity gradient and habitat preferences of Hemerodromiinae and Clinocerinae of central Europe, and one of only a few in the world.

Keywords: Hemerodromiinae; Clinocerinae; Empididae; species richness; altitudinal distribution; elevational diversity gradient; habitat preferences; Pieniny Mts.; Poland

\section{Introduction}

One of the most universal biogeographical patterns of species richness, known as the latitudinal gradient in species diversity, shows the decline of species richness from the 
tropics towards the Poles. The similarity between climatic factors at high altitudes and high latitudes suggests that the elevational richness gradient reflects the latitudinal richness gradient [1,2]. Many ecological studies reveal two main patterns of relationships between species richness and altitude: a monotonic decline in species richness with increasing elevation, and a hump-shaped relationship, with mid-elevation peaks in species richness [1]. Both models are well documented by studies focused on plants and vertebrates, especially birds and mammals [2-10]. Recent studies show that the second pattern seems to be more common [11-24]. On the other hand, relatively little was published on this topic in the case of insects, even if this is the most diverse animal group. Most studies were focused on butterflies, moths, ants, and beetles $[18,20,25-36]$. With respect to the flies, not many studies have been dedicated to the distributional patterns along the elevational gradient, which is usually explained by many difficulties occurring during field sampling [37-42]. Moreover, significantly more data are available for terrestrial insects [32,34-36] than for the aquatic groups, especially flies [43-48]. In addition, most of the studies mentioned above were done in the high mountain habitats located in the tropical regions. Very little is known about Diptera distributional patterns in lower mountain ranges [49], which is sometimes explained by the absence of significant climatic factors differentiating fauna in such mountain massifs including a lack of strict altitudinal zonation. Although more data are needed to confirm such hypothesis, generally it is known that the distribution of many fly species seems to be strictly connected with altitude, with some species occurring only in the higher parts of the mountains, others are known only from the lower elevations while some opportunistic taxa can be found along the entire elevational gradient.

Although aquatic Empididae is known as a good model group in biodiversity studies [50], current knowledge on elevational patterns of Hemerodromiinae and Clinocerinae flies is surprisingly insufficient and is based only on studies from the Doi Inthanon Mts. located in northern Thailand [51-56]. In the case of central Europe, including Poland, knowledge about elevational distribution preferences of aquatic dance flies is rudimentary and is based mainly on faunistic data with no advanced analysis of their ecological preferences [57-75]. Moreover, there is no detailed study focused on the elevational distribution of flies classified in any of these two subfamilies in lower mountain massifs.

Taking into account the data about aquatic empidids presented above, we aimed in the present paper to test the following hypotheses: 1 / species richness and distribution of Hemerodromiinae and Clinocerinae species are changing with the elevational gradient, 2 / occurrence of different aquatic dance fly species is correlated with the abiotic and/or biotic environmental parameters like altitude $(\mathrm{m})$, stream mean width $(\mathrm{cm})$, stream mean depth $(\mathrm{cm})$, shading $(\%)$, and dominant plant communities at the study sites, $3 /$ particular Hemerodromiinae and Clinocerinae species prefer similar types of habitat in different study sites.

\section{Materials and Methods}

\subsection{Study Area and Field Sampling}

The Pieniny Mts. are part of the Outer Western Carpathians and are divided into three smaller regions including Pieniny Właściwe, Little Pieniny (Pieniny Małe), and Pieniny Spiskie $[76,77]$. The mountain massif is a unique geological unit, composed of a variety of Jurassic and Cretaceous limestone, six kilometres wide and 35 kilometres long, and belongs to the Pieniny Klippen Belt [78,79]. Depending on the definition of the Pieniny Mts., with an average altitude of $630 \mathrm{~m}$, they are classified as a lower or medium mountain massif $[80,81]$. They can be characterized by the presence of only two altitudinal zones: foothills, which cover small areas and range below ca. $550 \mathrm{~m}$, and lower montane, which cover almost the entire massif. Such low values of height above ground level result in small altitudinal zonation especially in comparison to the higher mountain massifs located close to the Pieniny Mts., including Tatra Mts., Bieszczady Mts., or Babia Góra Mt. The streams in the Pieniny Mts. have various mountain exposure and have typical mountain character even if they are running along a median elevational gradient (410-770 m). In addition, 
the Dunajec River, which is a large mountain river collecting waters from all streams located in the Polish part of the massif, increases the mosaic of freshwater habitats in this region [82-84]. Although the Pieniny Mts. cover a relatively small area (ca. $\left.50 \mathrm{~km}^{2}\right)$, they can be characterized by a large mosaic of habitats having different microclimatic conditions that result in a high biodiversity. Based on Witkowski [85], over 7300 animal species and numerous plant species have been noted from this mountain massif, including both boreal and xerothermic taxa as well as glacial relicts or endemics to the Pieniny Mts. [86].

The study was carried out in the Polish part of the Pieniny Mts., Southern Poland, including Pieniny National Park, between April 1998 and November 2004. Materials were collected by the senior author (I.S.) on 46 sampling sites located on an elevational gradient between $420 \mathrm{~m}$ and $770 \mathrm{~m}$ (Table 1, Figure 1).

Table 1. Sampling sites in the Pieniny Mountains, southern Poland.

\begin{tabular}{|c|c|c|c|}
\hline No. & Sampling Site & Altitude (m) & GPS Location \\
\hline 1 & Łonny stream, headspring & 620 & $49^{\circ} 25^{\prime} 46^{\prime \prime} \mathrm{N} 20^{\circ} 24^{\prime} 56^{\prime \prime} \mathrm{E}$ \\
\hline 2 & Łonny stream & 560 & $49^{\circ} 25^{\prime} 51^{\prime \prime} \mathrm{N} 20^{\circ} 24^{\prime} 46^{\prime \prime} \mathrm{E}$ \\
\hline 3 & Łonny stream & 520 & $49^{\circ} 25^{\prime} 53^{\prime \prime} \mathrm{N} 20^{\circ} 24^{\prime} 44^{\prime \prime} \mathrm{E}$ \\
\hline 4 & Łonny stream & 463 & $49^{\circ} 26^{\prime} 11^{\prime \prime} \mathrm{N} 20^{\circ} 24^{\prime} 45^{\prime \prime} \mathrm{E}$ \\
\hline 5 & Łonny stream (outlet to the Krośnica stream) & 440 & $49^{\circ} 26^{\prime} 22^{\prime \prime} \mathrm{N} 20^{\circ} 24^{\prime} 43^{\prime \prime} \mathrm{E}$ \\
\hline 6 & Biały stream, headspring & 750 & $49^{\circ} 25^{\prime} 12^{\prime \prime} \mathrm{N} 20^{\circ} 23^{\prime} 09^{\prime \prime} \mathrm{E}$ \\
\hline 7 & Biały stream & 640 & $49^{\circ} 25^{\prime} 31^{\prime \prime} \mathrm{N} 20^{\circ} 23^{\prime} 09^{\prime \prime} \mathrm{E}$ \\
\hline 8 & Biały stream & 560 & $49^{\circ} 25^{\prime} 38^{\prime \prime} \mathrm{N} 20^{\circ} 23^{\prime} 14^{\prime \prime} \mathrm{E}$ \\
\hline 9 & Biały stream & 515 & $49^{\circ} 25^{\prime} 52^{\prime \prime} \mathrm{N} 20^{\circ} 23^{\prime} 43^{\prime \prime} \mathrm{E}$ \\
\hline 10 & Biały stream (outlet to the Krośnica stream) & 462 & $49^{\circ} 26^{\prime} 18^{\prime \prime} \mathrm{N} 20^{\circ} 23^{\prime} 45^{\prime \prime} \mathrm{E}$ \\
\hline 11 & Ociemny stream, headspring & 510 & $49^{\circ} 25^{\prime} 48^{\prime \prime} \mathrm{N} 20^{\circ} 25^{\prime} 55^{\prime \prime} \mathrm{E}$ \\
\hline 12 & Ociemny stream & 480 & $49^{\circ} 25^{\prime} 49^{\prime \prime} \mathrm{N} 20^{\circ} 25^{\prime} 59^{\prime \prime} \mathrm{E}$ \\
\hline 13 & Ociemny stream (outlet to the Dunajec River) & 445 & $49^{\circ} 25^{\prime} 54^{\prime \prime} \mathrm{N} 20^{\circ} 26^{\prime} 19^{\prime \prime} \mathrm{E}$ \\
\hline 14 & Kirowy stream, headspring & 770 & $49^{\circ} 25^{\prime} 02^{\prime \prime} \mathrm{N} 20^{\circ} 23^{\prime} 10^{\prime \prime} \mathrm{E}$ \\
\hline 15 & Kirowy stream & 680 & $49^{\circ} 24^{\prime} 51^{\prime \prime} \mathrm{N} 20^{\circ} 23^{\prime} 09^{\prime \prime} \mathrm{E}$ \\
\hline 16 & Kirowy stream & 610 & $49^{\circ} 24^{\prime} 45^{\prime \prime} \mathrm{N} 20^{\circ} 23^{\prime} 10^{\prime \prime} \mathrm{E}$ \\
\hline 17 & Macelowy stream & 587 & $49^{\circ} 24^{\prime} 38^{\prime \prime} \mathrm{N} 20^{\circ} 23^{\prime} 15^{\prime \prime} \mathrm{E}$ \\
\hline 18 & Macelowy stream & 560 & $49^{\circ} 24^{\prime} 35^{\prime \prime} \mathrm{N} 20^{\circ} 23^{\prime} 17^{\prime \prime} \mathrm{E}$ \\
\hline 19 & Macelowy stream, Sromowce Niżne village & 460 & $49^{\circ} 24^{\prime} 04^{\prime \prime} \mathrm{N} 20^{\circ} 24^{\prime} 35^{\prime \prime} \mathrm{E}$ \\
\hline 20 & Macelowy stream (outlet to the Dunajec River) & 450 & $49^{\circ} 24^{\prime} 22^{\prime \prime} \mathrm{N} 20^{\circ} 25^{\prime} 01^{\prime \prime} \mathrm{E}$ \\
\hline 21 & Sobczański stream, headspring & 750 & $49^{\circ} 25^{\prime} 01^{\prime \prime} \mathrm{N} 20^{\circ} 24^{\prime} 08^{\prime \prime} \mathrm{E}$ \\
\hline 22 & Sobczański stream & 655 & $49^{\circ} 24^{\prime} 55^{\prime \prime} \mathrm{N} 20^{\circ} 24^{\prime} 09^{\prime \prime} \mathrm{E}$ \\
\hline 23 & Sobczański stream & 590 & $49^{\circ} 24^{\prime} 50^{\prime \prime} \mathrm{N} 20^{\circ} 24^{\prime} 16^{\prime \prime} \mathrm{E}$ \\
\hline 24 & Sobczański stream & 530 & $49^{\circ} 24^{\prime} 38^{\prime \prime} \mathrm{N} 20^{\circ} 24^{\prime} 31^{\prime \prime} \mathrm{E}$ \\
\hline 25 & $\begin{array}{l}\text { Sobczański stream, (outlet to the Macelowy stream), Sromowce } \\
\text { Niżne village }\end{array}$ & 455 & $49^{\circ} 24^{\prime} 19^{\prime \prime} \mathrm{N} 20^{\circ} 24^{\prime} 45^{\prime \prime} \mathrm{E}$ \\
\hline 26 & Kotłowy stream, headspring & 610 & $49^{\circ} 24^{\prime} 39^{\prime \prime} \mathrm{N} 20^{\circ} 24^{\prime} 02^{\prime \prime} \mathrm{E}$ \\
\hline 27 & Kotłowy stream & 570 & $49^{\circ} 24^{\prime} 31^{\prime \prime} \mathrm{N} 20^{\circ} 24^{\prime} 01^{\prime \prime} \mathrm{E}$ \\
\hline 28 & Kotłowy stream (outlet to the Macelowy stream) & 490 & $49^{\circ} 24^{\prime} 10^{\prime \prime} \mathrm{N} 20^{\circ} 23^{\prime} 59^{\prime \prime} \mathrm{E}$ \\
\hline 29 & Krośnica stream, Krośnica village & 550 & $49^{\circ} 26^{\prime} 41^{\prime \prime} \mathrm{N} 20^{\circ} 20^{\prime} 43^{\prime \prime} \mathrm{E}$ \\
\hline
\end{tabular}


Table 1. Cont.

\begin{tabular}{|c|c|c|c|}
\hline No. & Sampling Site & Altitude (m) & GPS Location \\
\hline 30 & Krośnica stream, near Hałuszowa village & 520 & $49^{\circ} 26^{\prime} 13^{\prime \prime} \mathrm{N} 20^{\circ} 21^{\prime} 47^{\prime \prime} \mathrm{E}$ \\
\hline 31 & Krośnica stream, Tylka village & 462 & $49^{\circ} 26^{\prime} 20^{\prime \prime} \mathrm{N} 20^{\circ} 23^{\prime} 45^{\prime \prime} \mathrm{E}$ \\
\hline 32 & Krośnica stream, Krościenko village & 440 & $49^{\circ} 26^{\prime} 23^{\prime \prime} \mathrm{N} 20^{\circ} 24^{\prime} 49^{\prime \prime} \mathrm{E}$ \\
\hline 33 & Krośnica stream (outlet to the Dunajec River), Krościenko village & 415 & $49^{\circ} 26^{\prime} 33^{\prime \prime} \mathrm{N} 20^{\circ} 25^{\prime} 39^{\prime \prime} \mathrm{E}$ \\
\hline 34 & Dunajec River, Sromowce Wyżne village & 475 & $49^{\circ} 24^{\prime} 03^{\prime \prime} \mathrm{N} 20^{\circ} 21^{\prime} 12^{\prime \prime} \mathrm{E}$ \\
\hline 35 & Dunajec River, Kąty village & 465 & $49^{\circ} 24^{\prime} 25^{\prime \prime} \mathrm{N} 20^{\circ} 22^{\prime} 12^{\prime \prime} \mathrm{E}$ \\
\hline 36 & Dunajec River, Sromowce Niżne village & 455 & $49^{\circ} 24^{\prime} 22^{\prime \prime} \mathrm{N} 20^{\circ} 25^{\prime} 01^{\prime \prime} \mathrm{E}$ \\
\hline 37 & Dunajec River, Szczawnica & 430 & $49^{\circ} 26^{\prime} 26^{\prime \prime} \mathrm{N} 20^{\circ} 27^{\prime} 34^{\prime \prime} \mathrm{E}$ \\
\hline 38 & Dunajec River, Krościenko village & 420 & $49^{\circ} 26^{\prime} 27^{\prime \prime} \mathrm{N} 20^{\circ} 25^{\prime} 50^{\prime \prime} \mathrm{E}$ \\
\hline 39 & Małe Pieniny, Grajcarek stream, Jaworki village & 580 & $49^{\circ} 24^{\prime} 26^{\prime \prime} \mathrm{N} 20^{\circ} 33^{\prime} 14^{\prime \prime} \mathrm{E}$ \\
\hline 40 & Małe Pieniny, Grajcarek stream, Szlachtowa village & 540 & $49^{\circ} 24^{\prime} 37^{\prime \prime} \mathrm{N} 20^{\circ} 31^{\prime} 48^{\prime \prime} \mathrm{E}$ \\
\hline 41 & Małe Pieniny, Grajcarek stream & 490 & $49^{\circ} 25^{\prime} 03^{\prime \prime} \mathrm{N} 20^{\circ} 30^{\prime} 47^{\prime \prime} \mathrm{E}$ \\
\hline 42 & $\begin{array}{l}\text { Małe Pieniny, Grajcarek stream (outlet to the Dunajec River), } \\
\text { Szczawnica }\end{array}$ & 430 & $49^{\circ} 25^{\prime} 27^{\prime \prime} \mathrm{N} 20^{\circ} 27^{\prime} 35^{\prime \prime} \mathrm{E}$ \\
\hline 43 & Huliński stream & 745 & $49^{\circ} 24^{\prime} 56^{\prime \prime} \mathrm{N} 20^{\circ} 25^{\prime} 01^{\prime \prime} \mathrm{E}$ \\
\hline 44 & Huliński stream & 680 & $49^{\circ} 25^{\prime} \mathrm{VI}^{\prime \prime} \mathrm{N} 20^{\circ} 25^{\prime} 05^{\prime \prime} \mathrm{E}$ \\
\hline 45 & Huliński stream & 630 & $49^{\circ} 25^{\prime} 15^{\prime \prime} \mathrm{N} 20^{\circ} 25^{\prime} 04^{\prime \prime} \mathrm{E}$ \\
\hline 46 & Huliński stream (outlet to the Pieniński stream) & 587 & $49^{\circ} 25^{\prime} 25^{\prime \prime} \mathrm{N} 20^{\circ} 25^{\prime} 13^{\prime \prime} \mathrm{E}$ \\
\hline
\end{tabular}

During the sampling period, each site was visited three times per year: in spring, summer, and autumn. The Hemerodromiinae and Clinocerinae flies were collected along the following streams located in the national park, from headsprings to their outlets: Łonny, Biały, Ociemny, Huliński, Kirowy, Macelowy, Kotłowy, Sobczański, as well as along sections of the Krośnica stream, the Dunajec River (all located in the Pieniny Właściwe Mts.) and the Grajcarek stream (placed in the Little Pieniny Mts.) (Figure 2). The sampling procedure consisted of starting the gathering at the site near the headspring (if applicable), and proceeding downstream over the course of the day. Each stream was sampled over the course of a single day. On each sampling site, both abiotic and biotic environmental parameters were measured including: altitude $(\mathrm{m})$, stream mean width $(\mathrm{cm})$, stream mean depth $(\mathrm{cm})$, shading $(\%)$, and dominant plant communities at the study site. The width and depth of the streams and rivers were measured each time material was sampled. In the analysis, only average values were used. Adults of Hemerodromiinae and Clinocerinae were captured using a sweep net or collected with tweezers (directly from stones protruding from the water, moss overgrowing rocks, etc.). At each sampling site, flies were collected for ca. 90 minutes. During the first half of the sampling period, materials were collected from emergent stones. The second 45 minute period was focused on sampling from vegetation along the banks of the stream. Both shaded and sunny areas were checked for Clinocerinae and Hemerodromiinae species presence. To exclude the potential impact of weather on the aquatic empidids activity, samples were not collected during rainfall. Each sampling site was defined as a length of ca. $20 \mathrm{~m}$ of the stream measured on both of its sides. The material (in total 42,155 individuals) was preserved in $75 \%$ ethanol and later identified in the laboratory by the senior author (I.S.); currently, it is deposited in the Department of Invertebrate Zoology and Hydrobiology of the University of Lodz (Łódź, Poland). 

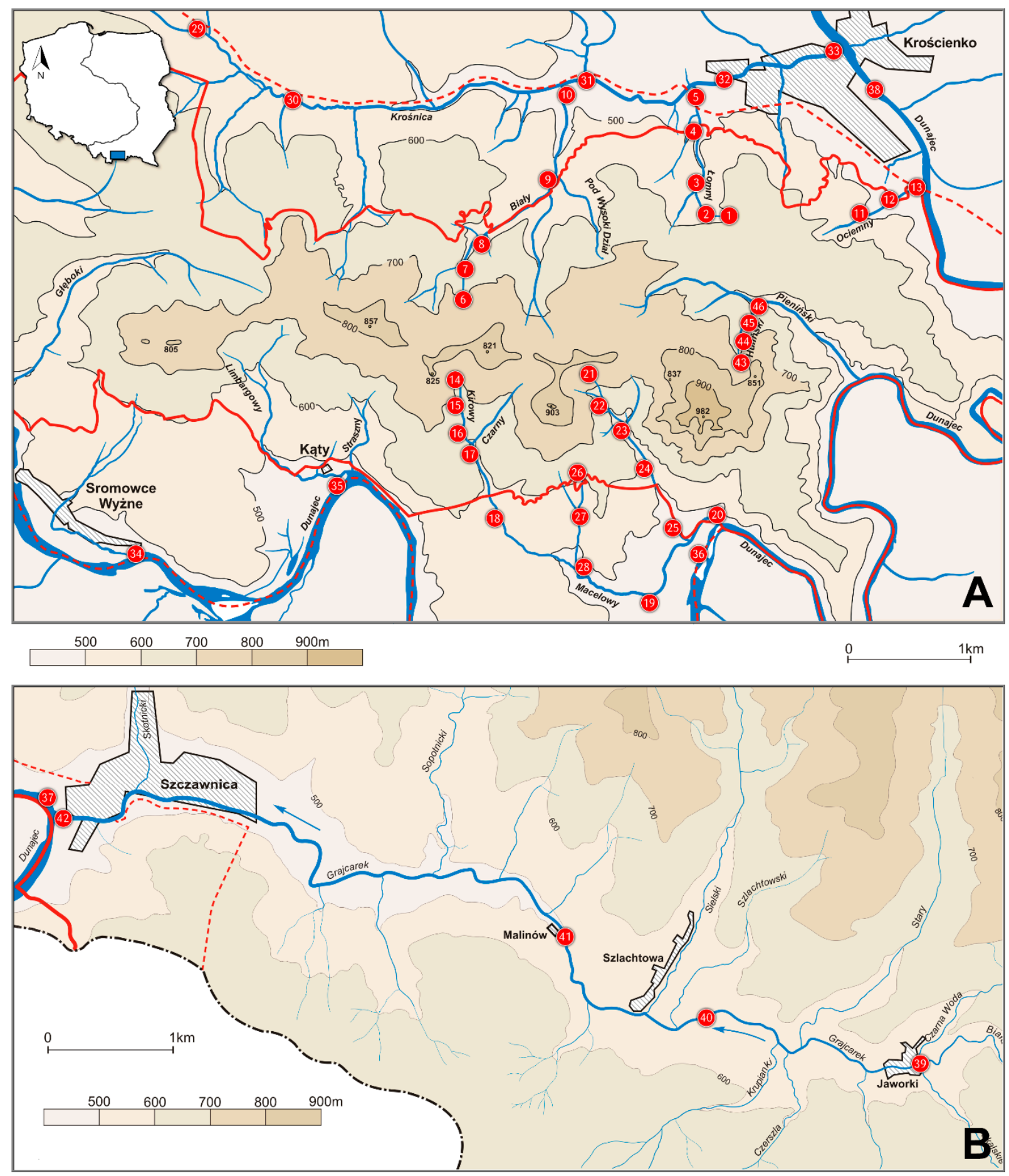

Figure 1. Localities of sampling sites in the Pieniny Mts., Poland: (A) Pieniny Właściwe (including Pieniny National Park and its buffer zone), (B) Little Pieniny (Małe Pieniny). 


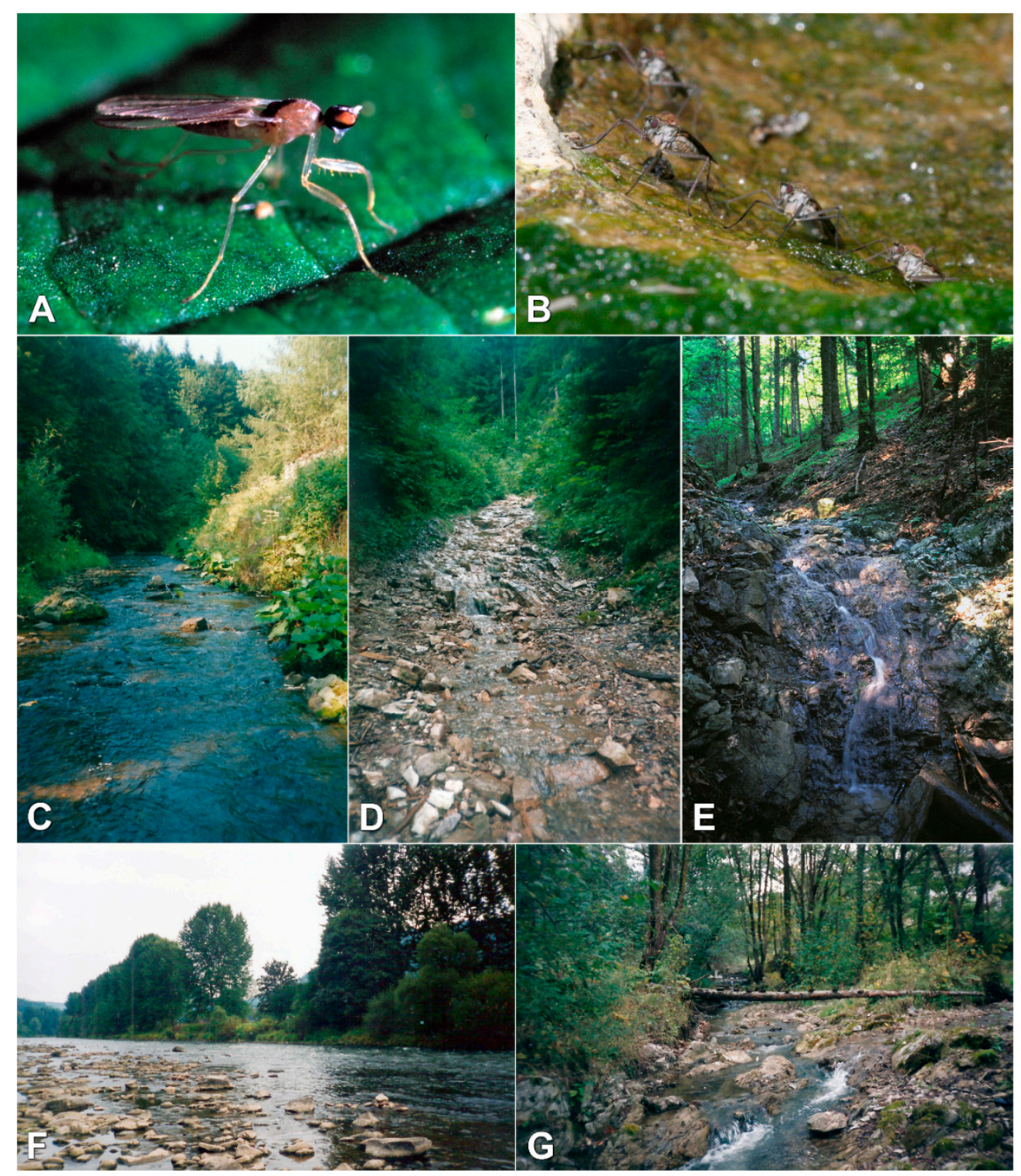

Figure 2. Some empidid species (A,B) and their habitats (C-G) in the study area. (A) Female of Hemerodromia unilineata (Hemerodromiinae), (B) Group of Wiedemannia bistigma (Clinocerinae) on the boulder in the Dunajec River, (C) Krośnica stream (sampling site no. 32), (D) Sobczański stream (sampling site no. 23), (E) Kirowy stream (sampling site no. 15), (F) Dunajec River (sampling site no. 38), (G) Grajcarek stream (sampling site no. 39) (phot. A-A. Palaczyk, B-G-I. Słowińska).

\subsection{Statistical Methods}

The numbers of species and individuals for the two main altitudinal zones - foothills (F) and lower montane (LM) were accounted separately for Hemerodromiinae and Clinocerinae flies. To examine the elevational distribution of both subfamilies, the altitudinal ranges were divided into eight bands, each with an altitudinal value of $50 \mathrm{~m}$ : 400-450 m (B1), 451-500 m (B2), 501-550 m (B3), 551-600 m (B4), 601-650 m (B5), 651-700 m (B6), 701-750 m (B7), and $>750 \mathrm{~m}$ (B8) (Table 2). In order to determine the constancy of occurrence for each species, the frequency was used, which expressed the relation of the number of sites where the species occurred to the number of all the studied sites. Five classes of frequency were distinguished: euconstants $>75.0 \%$, constants $55.1-75.0 \%$, subconstants $35.1-55.0 \%$, accessory species $15.1-35.0 \%$, and accidents $<15.0 \%$. The diversity was evaluated using the following indices: species richness (S), the Shannon Index $\left(\mathrm{H}^{\prime}\right)$, the Simpson Index (D), and Margalef's $\left(D_{M g}\right)$ and Pielou Evenness $\left(J^{\prime}\right)$ indices. 
Table 2. Elevational distribution of Hemerodromiinae and Clinocerinae along the altitudinal ranges at the foothills and the lower montane zones in the Pieniny Mts., Poland.

\begin{tabular}{|c|c|c|c|c|c|c|c|c|c|c|}
\hline \multirow[b]{2}{*}{ Altitude (m) } & \multicolumn{4}{|c|}{ Foothills Zone (F) } & \multicolumn{6}{|c|}{ Lower Montane Zone (LM) } \\
\hline & $\begin{array}{l}400-450 \\
\text { (B1) }\end{array}$ & $\begin{array}{l}451-500 \\
\text { (B2) }\end{array}$ & $\begin{array}{l}501-550 \\
\text { (B3) }\end{array}$ & Total & $\begin{array}{l}551-600 \\
\text { (B4) }\end{array}$ & $\begin{array}{l}\text { 601-650 } \\
\text { (B5) }\end{array}$ & $\begin{array}{l}\text { 651-700 } \\
\text { (B6) }\end{array}$ & $\begin{array}{l}701-750 \\
\text { (B7) }\end{array}$ & $\begin{array}{l}>751 \\
(\mathrm{~B} 8)\end{array}$ & Total \\
\hline Number of Hemerodromiinae species & 10 & 8 & 8 & 12 & 9 & 8 & 6 & 5 & 3 & 14 \\
\hline Number of Hemerodromiinae individuals & 355 & 158 & 137 & 650 & 147 & 78 & 67 & 65 & 10 & 367 \\
\hline Chelifera angusta Collin, 1927 & 3 & & & 3 & 1 & & & & & 1 \\
\hline Chelifera aperticauda Collin, 1927 & 1 & & & 1 & & & & & & \\
\hline Chelifera astigma Collin, 1927 & 1 & 11 & 1 & 13 & & & & 3 & & 3 \\
\hline Chelifera concinnicauda Collin, 1927 & 184 & 10 & 11 & 205 & 5 & 1 & & & & 6 \\
\hline Chelifera flavella (Zetterstedt, 1838) & & 1 & 11 & 12 & & 10 & & 53 & 8 & 71 \\
\hline Chelifera pectinicauda Collin, 1927 & & & & & & & & & 1 & 1 \\
\hline Chelifera precabunda Collin, 1961 & 15 & 4 & 6 & 25 & 18 & 5 & 4 & 5 & & 32 \\
\hline Chelifera precatoria (Fallén, 1816) & 7 & 6 & 13 & 26 & 4 & & 2 & & & 6 \\
\hline Chelifera stigmatica (Schiner, 1862) & 59 & 59 & 48 & 166 & 41 & 4 & 3 & & & 48 \\
\hline Chelifera subangusta Collin, 1961 & & & & & & & 1 & 1 & & 2 \\
\hline Chelifera trapezina (Zetterstedt, 1838) & 24 & 47 & 46 & 117 & 64 & 30 & 56 & 3 & 1 & 154 \\
\hline Chelipoda vocatoria (Fallén, 1816) & & & & & & 1 & 1 & & & 2 \\
\hline Hemerodromia melangyna Collin, 1927 & & & 1 & 1 & 1 & 1 & & & & 2 \\
\hline Hemerodromia oratoria (Fallén, 1816) & 21 & & & 21 & & & & & & \\
\hline Hemerodromia unilineata Zetterstedt, 1842 & 40 & 20 & & 60 & 1 & & & & & 1 \\
\hline Phyllodromia melanocephala (Fabricius, 1794) & & & & & 12 & 26 & & & & 38 \\
\hline Number of Clinocerinae species & 12 & 15 & 18 & 22 & 18 & 11 & 9 & 7 & 7 & 19 \\
\hline Number of Clinocerinae individuals & 13,387 & 20,751 & 4594 & 38,732 & 1224 & 394 & 497 & 185 & 106 & 2406 \\
\hline Clinocera appendiculata (Zetterstedt, 1838) & & & & & 1 & 23 & 5 & 30 & 1 & 60 \\
\hline Clinocera fontinalis (Haliday, 1833) & & & & & 1 & & & & 1 & 2 \\
\hline Clinocera wesmaeli (Macquart, 1835) & & 2 & 17 & 19 & 23 & 1 & 5 & 2 & 8 & 39 \\
\hline Dolichocephala guttata (Haliday, 1833) & & 2 & & 2 & & 1 & 2 & 3 & & 6 \\
\hline Dolichocephala irrorata (Fallén, 1816) & 4 & & 12 & 16 & 2 & 1 & & & & 3 \\
\hline Dolichocephala oblongoguttata (Dale, 1878) & & & 1 & 1 & 1 & 3 & 1 & 1 & & 6 \\
\hline Kowarzia plectrum (Mik, 1880) & & 67 & 267 & 334 & 256 & 173 & 439 & 137 & 84 & 1089 \\
\hline Wiedemannia bistigma (Curtis, 1834) & 5932 & 16,146 & 53 & 22,131 & 6 & & & & & 6 \\
\hline Wiedemannia bohemani (Zetterstedt, 1838) & 28 & 99 & 28 & 155 & 2 & & & & & 2 \\
\hline Wiedemannia braueri (Mik, 1880) & 3657 & 2542 & 1231 & 7430 & 57 & & & & & 57 \\
\hline Wiedemannia fallaciosa (Loew, 1873) & 404 & 583 & 1449 & 2436 & 85 & 13 & & & & 98 \\
\hline Wiedemannia hygrobia (Loew, 1858) & 10 & 12 & 105 & 127 & 37 & 2 & & & & 39 \\
\hline Wiedemannia jakubi Krysiak, 2005 & & & 1 & 1 & & & & & & \\
\hline Wiedemannia jazdzewskii Niesiolowski, 1987 & & & 21 & 21 & 21 & 159 & 34 & 2 & 4 & 220 \\
\hline Wiedemannia lamellata (Loew, 1869) & & 35 & & 35 & & & & & & \\
\hline Wiedemannia mikiana (Bezzi, 1899) & & & 5 & 5 & & & & & & \\
\hline Wiedemannia phantasma (Mik, 1880) & 5 & & & 5 & & & & & & \\
\hline $\begin{array}{l}\text { Wiedemannia pieninensis Krysiak et } \\
\text { Niesiolowski, } 2004\end{array}$ & & & 4 & 4 & 1 & & 4 & & 1 & 6 \\
\hline Wiedemannia pirata (Mik, 1880) & 90 & 40 & 347 & 477 & 31 & & & & & 31 \\
\hline Wiedemannia rhynchops (Nowicki, 1868) & 4 & 53 & 104 & 161 & 86 & & & & & 86 \\
\hline Wiedemannia stylifera Mik, 1889 & 57 & 119 & 691 & 867 & 298 & & & & & 298 \\
\hline Wiedemannia thienemanni Wagner, 1982 & & 9 & 9 & 18 & 32 & 3 & 6 & 10 & 7 & 58 \\
\hline Wiedemannia tricuspidata (Bezzi, 1905) & 3084 & 696 & & 3780 & & & & & & \\
\hline Wiedemannia zetterstedti (Fallén, 1816) & 112 & 346 & 249 & 707 & 284 & 15 & 1 & & & 300 \\
\hline
\end{tabular}

Forty Empididae species (16 Hemerodromiinae and 24 Clinocerinae) collected in 46 samples from the Pieniny Mountains were used in the multivariate analysis. All multivariate analyses were based on square-root transformed semiquantitative biotic data. 
Additionally, 17 environmental variables were measured (1) abiotic: altitude (m), stream mean width $(\mathrm{cm})$, stream mean depth $(\mathrm{cm})$, shading $(\%)$, and (2) biotic-dominant plant communities at the study site on a 0-3 scale: beech mountain forest (B), fir mountain forest $(\mathrm{J})$, eutrophic brook flora (EMG), alder forest $(\mathrm{O})$, burdock brake (LOP), rocky grasslands $(\mathrm{MN})$, pasture $(\mathrm{P})$, meadow $(\mathrm{LK})$, tree plantations $(\mathrm{DN})$, willow brake $(\mathrm{ZW})$, sycamore mountain community altitudinal zones forests (JAW), xerothermic grasslands (MKS), and crop fields (PU).

The SIMPER analysis was conducted using a Bray-Curtis similarity index and 100\% cut off for low contributions as a proposal to find patterns of species distribution in the Pieniny Mts. The SIMPER analysis was separately calculated for Hemerodromiinae and Clinocerinae subfamilies, comparing species composition between two sample groups: $\mathrm{F}$ (foothills $\leq 550 \mathrm{~m}$ ) and LM (lower montane zone $>550 \mathrm{~m}$ ).

To obtain the main environmental factors influencing dipteran communities, an ordination analysis was conducted. The detrended correspondence analysis (DCA) was calculated with detrending by segments and downweighting rare species, to recognize the data distribution (linear or unimodal). As the lengths of the gradient for the first and second DCA axes were respectively 5.523 SD and 5.259 SD units, a canonical correspondence analysis (CCA) was calculated for environment and biota variables comparison. CCA was calculated on inter-species distance with Hill's scaling anddownweighting rare species. As there was no autocorrelation between environmental variables, they were all included in the analysis. The full model, unrestricted Monte-Carlo permutation test was calculated using automatic selection to indicate the significance of the relation of biota-environmental variables. Because CCA triplot revealed the arch effect, a detrended canonical correspondence analysis (DCCA) was also conducted with detrending by segments and downweighting rare species. Unrestricted Monte-Carlo permutation test was performed to obtain the significance of the first ordination axis under the full model.

The multivariate analysis was calculated using PRIMER 6 and Canoco 4.5 software $[87,88]$.

\section{Results}

\subsection{Species Composition, Species Richness and Diversity along the Elevational Zones}

In total 42,155 individuals belonging to 40 species of aquatic empidids have been collected from 46 sampling sites from the Pieniny Mts. Among them, eleven species are known as rare including four currently recognized as endemics to this mountain massif $[61,63,89]$. Aquatic empidids were decidedly dominated by the subfamily Clinocerinae (almost 98\% total fauna) which was represented by 24 species grouped in four genera: Clinocera Meigen, 1803 (3 species), Dolichocephala Macquart, 1823 (3 species), Kowarzia Mik, 1881 (1 species), Wiedemannia Zetterstedt, 1838 (17 species). The subfamily Hemerodromiinae was represented by 16 species classified in four genera: Chelifera Macquart, 1823 (11 species), Chelipoda Macquart, 1823 (1 species), Hemerodromia Meigen, 1822 (3 species), and Phyllodromia Zetterstedt, 1837 (1 species). The most abundant species were Wiedemannia bistigma with a total of 22,137 (53.8\% of Clinocerinae fauna) and Chelifera trapezina with a total of 271 (26.6\% of Hemerodromiinae fauna). In total, almost $60 \%$ of all aquatic empidids collected in the study were caught in the Dunajec, the major river in the Pieniny Mts., with Wiedemannia bistigma as the most abundant species recorded at all sampling sites along this river (19,038 individuals or $46.3 \%$ of clinocerines). Nine species were represented by less than 10 individuals, three species were singletons and two species were doubletons.

The distribution of aquatic empidids by the altitudinal zones shows that 12 Hemerodromiinae and 22 Clinocerinae species occur at the foothills zone (F) while at the lower montane zone (LM) these groups are represented by 14 and 19 species respectively (Figure 3, Table 2). For both families, the highest number of individuals was recorded at the foothills (650 of Hemerodromiinae and 38,732 of Clinocerinae). Seven species (17.5\% of total fauna) were found exclusively at the foothills including Chelifera aperticauda, Hemerodromia oratoria (Hemerodromiinae), Wiedemannia jakubi, W. lamellata, W. mikiana, W. phantasma, and W. tricuspidata (Clinocerinae) while six species (15\%) were restricted to the lower montane zone: 
Chelifera pectinicauda, C. subangusta, Chelipoda vocatoria, Phyllodromia melanocephala (Hemerodromiinae), Clinocera appendiculata, and C. fontinalis (Clinocerinae). Another five aquatic empidids were found as more opportunistic taxa which can occur at both the foothills and the lower montane zone (Chelifera precabunda, C. stigmatica, C. trapezina, Dolichocephala guttata, Wiedemannia pieninensis) (Table 2).

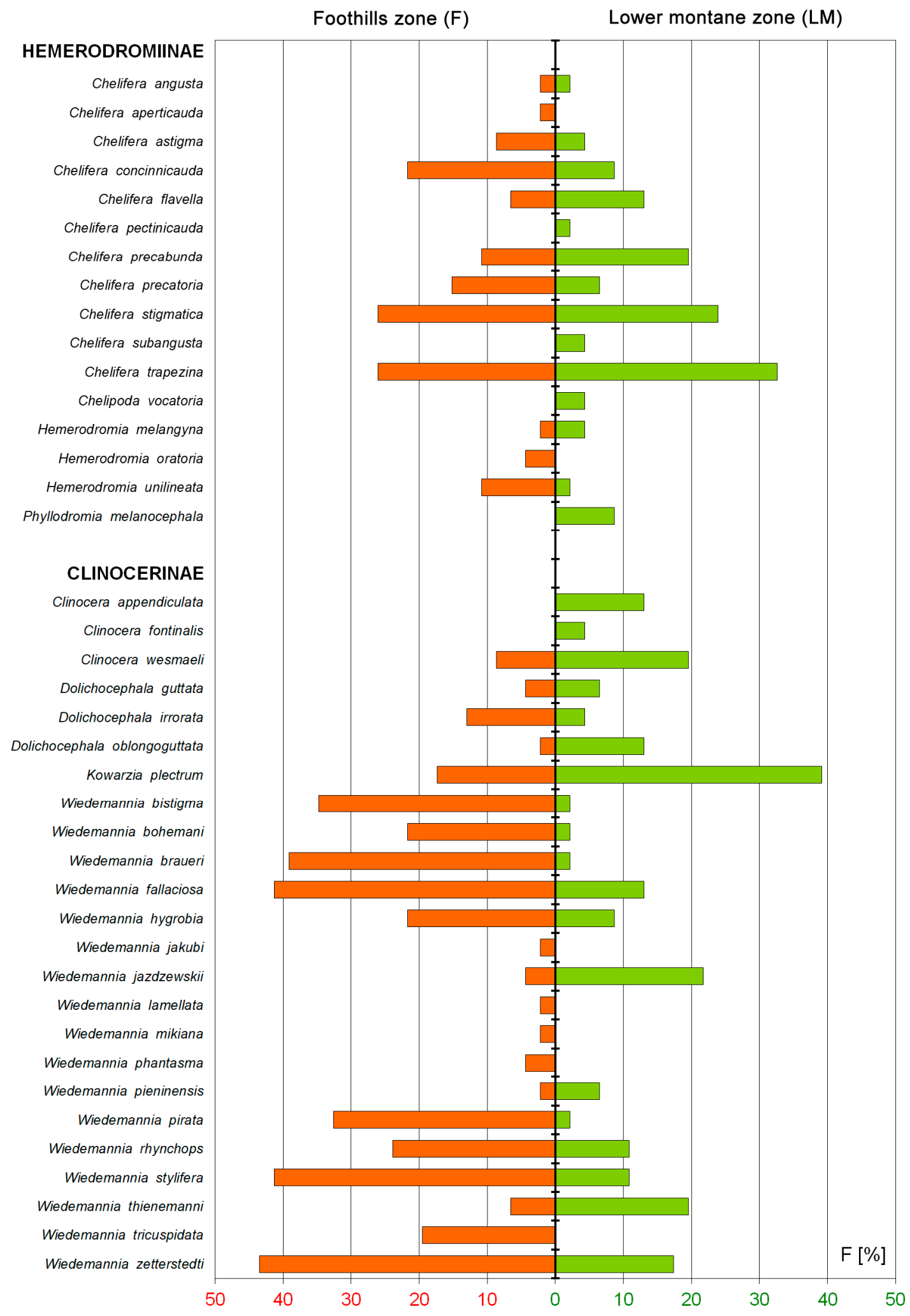

Figure 3. Frequency of Hemerodromiinae and Clinocerinae at the foothills zone and the lower montane zone in the Pieniny Mts. 
Species richness of the Clinocerinae subfamily gradually increased with altitude with a peak at the middle ranges, 501-550 m (B3) and 551-600 $\mathrm{m}$ (B4), and then decreased with increasing elevation (Figure 4). Although for these two bands the highest species richness was recorded, it was only in B4 that the highest values of Shannon's, Simpson's, Margalef's and Pielou Evenness indices were noted (Table 3). This was reflected in the large number of species (18) recorded at this altitude interval, which decreased with the further increase in elevation to only seven species above $750 \mathrm{~m}$ (B8). On the other hand, at 451-500 m (B2) there were only three fewer species but all of the estimated indices, except Margalef's, were lower than at 551-600 m (B4). It is worth noting that over $77 \%$ of the individuals found on the entire altitudinal range B2 $(451-500 \mathrm{~m})$ belong to one species, Wiedemannia bistigma (the most abundant clinocerine species found by us in the Pieniny Mts.).
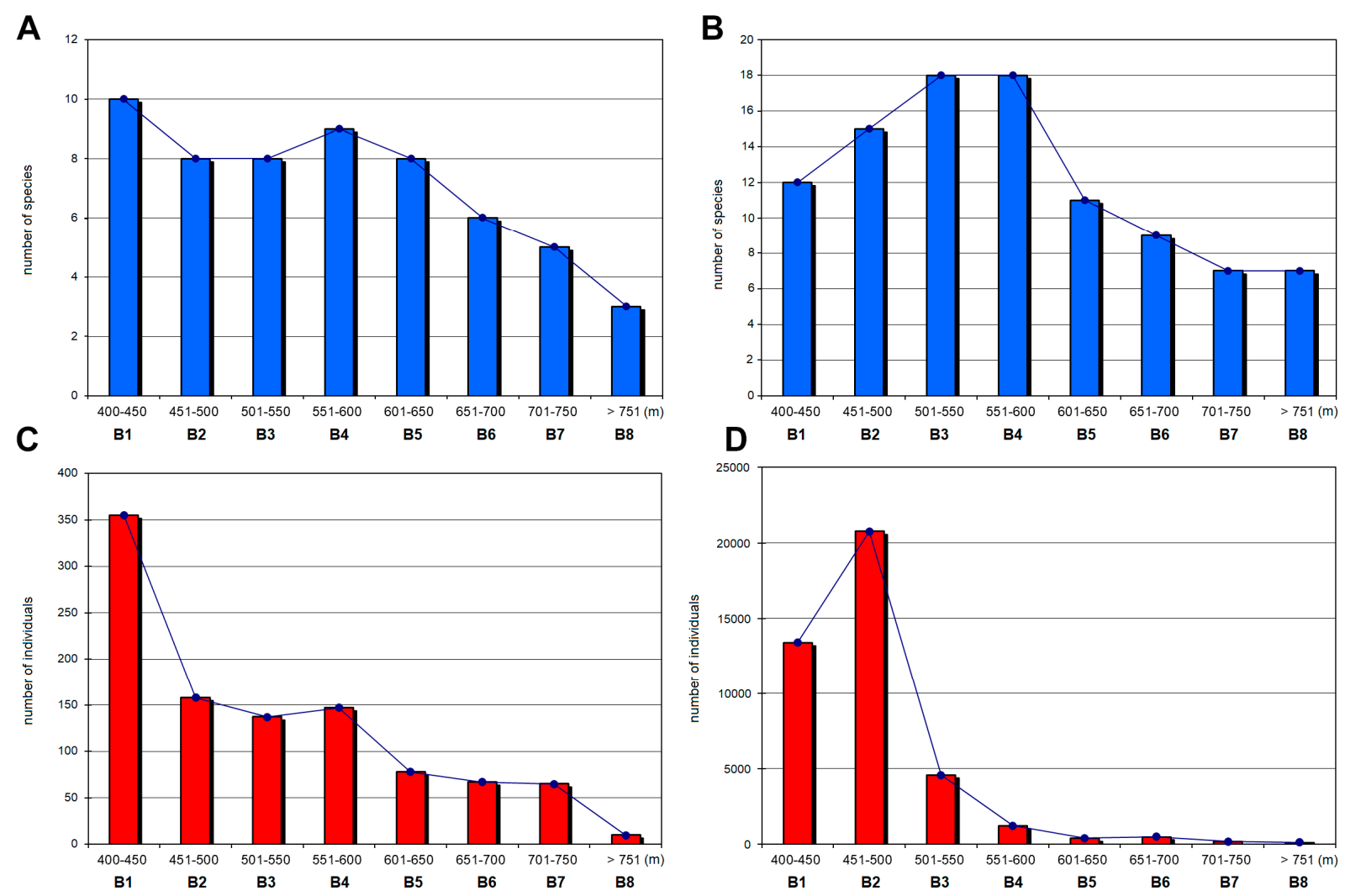

Figure 4. Species richness $(\mathbf{A}, \mathbf{B})$ and the number of individuals $(\mathbf{C}, \mathbf{D})$ along the altitudinal bands calculated for the subfamilies Hemerodromiinae $(\mathbf{A}, \mathbf{C})$ and Clinocerinae $(\mathbf{B}, \mathbf{D})$.

In examining the species richness of the subfamily Hemerodromiinae across each elevational band, a downwards trend with increasing altitude was apparent, although species richness was the highest at the lowest zone (400-450 m; B1). The results of all estimated indices for this band were relatively lower compared with those obtained at higher elevations (Table 3).

Overall, both subfamilies were more abundant at the two lowest elevational zones (B1-Hemerodromiinae, B2-Clinocerinae). These intervals generated the greatest number of individuals but did not generate a correspondingly greater number of species. This could be due to the location of sites along the Dunajec River, which provide the maximum number of clinocerines. Approximately 24,236 of the individuals collected from this river comprised three species: Wiedemannia bistigma, W. braueri, and W. tricuspidata. There was a significant increase in clinocerine abundance at the band B2 (451-500 m). Increased clinocerine numbers at this interval were mainly due to the presence of $W$. bistigma at each site along Dunajec River. 
Table 3. Species richness and diversity indices calculated for eight altitudinal zones.

\begin{tabular}{|c|c|c|c|c|c|c|c|c|}
\hline \multirow[b]{2}{*}{ Altitude (m) } & \multicolumn{3}{|c|}{ Foothills Zone (F) } & \multicolumn{5}{|c|}{ Lower Montane Zone (LM) } \\
\hline & $\begin{array}{c}400-450 \\
\text { (B1) }\end{array}$ & $\begin{array}{c}451-500 \\
\text { (B2) }\end{array}$ & $\begin{array}{l}501-550 \\
\text { (B3) }\end{array}$ & $\begin{array}{l}551-600 \\
\text { (B4) }\end{array}$ & $\begin{array}{c}601-650 \\
\text { (B5) }\end{array}$ & $\begin{array}{c}651-700 \\
\text { (B6) }\end{array}$ & $\begin{array}{c}701-750 \\
\text { (B7) }\end{array}$ & $>750$ (B8) \\
\hline \multicolumn{9}{|l|}{ Hemerodromiinae } \\
\hline Species richness & 10 & 8 & 8 & 9 & 8 & 6 & 5 & 3 \\
\hline Shannon-Wiener Index $\left(H^{\prime}\right)$ & 1.52 & 1.6 & 1.57 & 1.5 & 1.49 & 0.69 & 0.71 & 0.64 \\
\hline Simpson's Index $(D)$ & 0.68 & 0.75 & 0.74 & 0.71 & 0.72 & 0.29 & 0.33 & 0.34 \\
\hline Margalef Index $\left(D_{M g}\right)$ & 1.53 & 1.38 & 1.42 & 1.6 & 1.61 & 1.19 & 0.96 & 0.87 \\
\hline Pielou Evenness Index $\left(J^{\prime}\right)$ & 0.66 & 0.77 & 0.76 & 0.68 & 0.72 & 0.38 & 0.44 & 0.58 \\
\hline \multicolumn{9}{|l|}{ Clinocerinae } \\
\hline Species richness & 12 & 15 & 18 & 18 & 11 & 9 & 7 & 7 \\
\hline Shannon-Wiener Index $\left(H^{\prime}\right)$ & 1.28 & 0.86 & 1.87 & 2.03 & 1.28 & 0.53 & 0.87 & 0.81 \\
\hline Simpson's Index $(D)$ & 0.68 & 0.38 & 0.79 & 0.83 & 0.64 & 0.22 & 0.42 & 0.36 \\
\hline Margalef Index $\left(D_{M g}\right)$ & 1.16 & 1.41 & 2.02 & 2.39 & 1.67 & 1.29 & 1.15 & 1.29 \\
\hline Pielou Evenness Index $\left(J^{\prime}\right)$ & 0.52 & 0.32 & 0.65 & 0.7 & 0.53 & 0.24 & 0.45 & 0.42 \\
\hline
\end{tabular}

The highest number of Hemerodromiinae individuals were recorded at the lowest elevation (B1) with 355 individuals of which more than half was Chelifera concinnicauda. In the next elevational band (B2) a dramatic decrease of Hemerodromiinae individuals was noted. Above $750 \mathrm{~m}$ (B8), both species richness and the number of individuals clearly decreased (Figure 4). Moreover, the values of calculated indices were relatively low.

Both subfamilies were not evenly distributed along the altitudinal ranges (Table 2). Wiedemannia bistigma, W. braueri, W. tricuspidata, W. lamellata, and W. phantasma were the main species contributing to the low-elevation communities (below $550 \mathrm{~m}$ ). All these species occurred mainly along the Dunajec River and Krośnica stream (both placed at the foot of the Pieniny Mts.), and also in the lower stream sections but only in the outlets to the Dunajec River. The most abundant Clinocerinae species, -W. bistigma, W. bohemani, $W$. braueri, W. pirata, W. rhynchops, W. stylifera and W. tricuspidata-had a similar distribution pattern of decreasing numbers with altitude. Interestingly, all mentioned species were absent above $600 \mathrm{~m}$, whereas $W$. tricuspidata did not exceed $500 \mathrm{~m}$.

Among the Hemerodromiinae, two species-Chelifera concinnicauda and C. stigmaticawere the main contributing species to the low-elevation communities.

For the high elevations, Clinocera appendiculata, C. fontinalis, Dolichocephala guttata, D. oblongoguttata, Kowarzia plectrum, Wiedemannia jazdzewskii, and W. thienemanni (Clinocerinae), as well as Chelifera flavella, C. pectinicauda, C. subangusta, Chelipoda vocatoria, and Phyllodromia melanocephala (Hemerodromiinae) were the main contributing species. However, Chelifera trapezina was found to occur in all elevational intervals and it was most abundant in the middle elevation (551-600 m; B4).

Some species were noted only in one interval, including Chelifera aperticauda, Hemerodromia oratoria, and Wiedemannia phantasma in band $1(400-450 \mathrm{~m})$, W. lamellata in band 2 (451-500 m), W. jakubi and W. mikiana in band 3 (501-550 m), and Chelifera pectinicauda in band 8 (>750 m).

Others, even though occurring throughout almost all elevational ranges, presented a higher abundance in certain altitudes, such as C. precabunda, C. trapezina, C. wesmaeli, and Wiedemannia thienemanni at the middle range (551-600 m; B4), Kowarzia plectrum at 651-700 m (B6), Wiedemannia jazdzewskii at 601-650 m (B5), and W. zetterstedti at 451-500 m (B2). 


\subsection{Biotic and Abiotic Factors vs. Distribution at the Altitudinal Zones}

The SIMPER analysis indicated that Clinocerinae and Hemerodromiinae communities reveal clear dissimilarity ( $88.81 \%$ and $82.46 \%$ respectively) for the foothills (F) and the lower montane (LM) altitudinal zones. The communities of both altitudinal zones have also low specific similarity (Clinocerinae: $\mathrm{F}=28.6 \%, \mathrm{LM}=16.31 \%$; Hemerodromiinae: $\mathrm{F}=13.84 \%$, $\mathrm{LM}=28.76 \%$ ). Among the three Clinocerinae taxa that contribute mostly to the foothills (F) communities, only Wiedemannia zetterstedti was also a common dominant at the lower montane zone (LM). W. braueri and W. bistigma were specific for $\mathrm{F}$ and $W$. jazdzewskii with $W$. thienemanni remaining specific for the LM. Otherwise, among Hemerodromiinae, the two most contributing taxa for the F and LM-Chelifera trapezina and C. stigmatica-were the common dominants for both altitudinal zones. Among the three main dominants, only Chelifera concinnicauda and C. flavella remained specific for the F and LM respectively. Using the environmental variables, the first and second CCA axes explained respectively $22.7 \%$ and $11.9 \%$ of species data percentage variance as well as $41.7 \%$ and $21.9 \%$ of speciesenvironment relation percentage variance (Figure 5). Five of seventeen environmental variables significantly explained biota variance: altitude $(p=0.002$, explaining $16.7 \%$ of biota variance, $\lambda 1: \lambda 2=1.17)$, stream mean width $(p=0.002$, explaining $9.3 \%$ of biota variance, $\lambda 1: \lambda 2=0.83), \mathrm{B}(p=0.002$, explaining $5.25 \%$ of biota variance, $\lambda 1: \lambda 2=0.58)$, $\mathrm{ZW}(p=0.002$, explaining $4.0 \%$ of biota variance, $\lambda 1: \lambda 2=0.50)$, and shading $(p=0.01$, explaining $3.4 \%$ of biota variance, $\lambda 1: \lambda 2=1.02)$. The first and second DCCA axes explained respectively $22.7 \%$ and $3.5 \%$ of species data percentage variance as well as $40.7 \%$ and $8.1 \%$ of species-environment relation percentage variance. The test of significance of the first canonical DCCA axis revealed eigenvalue $=0.736$, F-ratio $=8.233$, and $p$-value $=0.002$. Stream mean width, stream mean depth, $\mathrm{P}$ and $\mathrm{ZW}$ were positively correlated with DCCA axis 1. Altitude, shading, B, and J were negatively correlated with DCCA axis 1. Only insignificant to CCA Monte-Carlo test, EMG was negatively correlated with DCCA axis 2. Environmental plant community variables O, LOP, MN, LK, DN, JAW, MKS, and PU were not correlated with the first two DCCA axes. Communities typical to the LM zone were distributed only at a higher altitude, shading, and B. Communities from the F zone were distributed generally at a lower altitude and shading and were spread along wider streams with willow vegetation. Only samples from $12,11,3$, and $4 \mathrm{P}$ sites, were localized at the shaded beech forests $(B)$ representing also higher altitudes (463-520 m). Chelifera pectinicauda, C. flavella, C. subangusta, and Phyllodromia melanocephala among Hemerodromiinae, and Clinocera appendiculata, C. fontinalis, C. wesmaeli, Dolichocephala guttata, D. oblongoguttata, Kowarzia plectrum, Wiedemannia jazdzewskii, and W. thienemanni among Clinocerinae are taxa clearly associated with the highest altitudes and shading in the Pieniny Mountains. They are also frequent in beech forests. W. bistigma, W. lamellata, W. phantasma, and W. tricuspidata from the Clinocerinae are clearly associated with lower elevated, wider stream valleys overgrown by willow brakes that give less shading than LM beech mountain forests. Other taxa revealed more or less intermediate preferences according to the environmental variables measured. Chelifera subangusta, Hemerodromia oratoria, and Wiedemannia mikiana revealed a strong/stronger correlation with the 2nd DCCA axis than the 1st DCCA axis. Interestingly, Hemerodromiinae revealed lower 2nd DCCA axis values whereas for Clinocerinae, more frequently significant the 2nd CCA axis variance came out. Other, not included factors (maybe some like EMG i.e., soil/water chemistry, trophy, or ground/stream bank microhabitat quality) may determine the distributional pattern of these two subfamilies in the Pieniny Mts. 


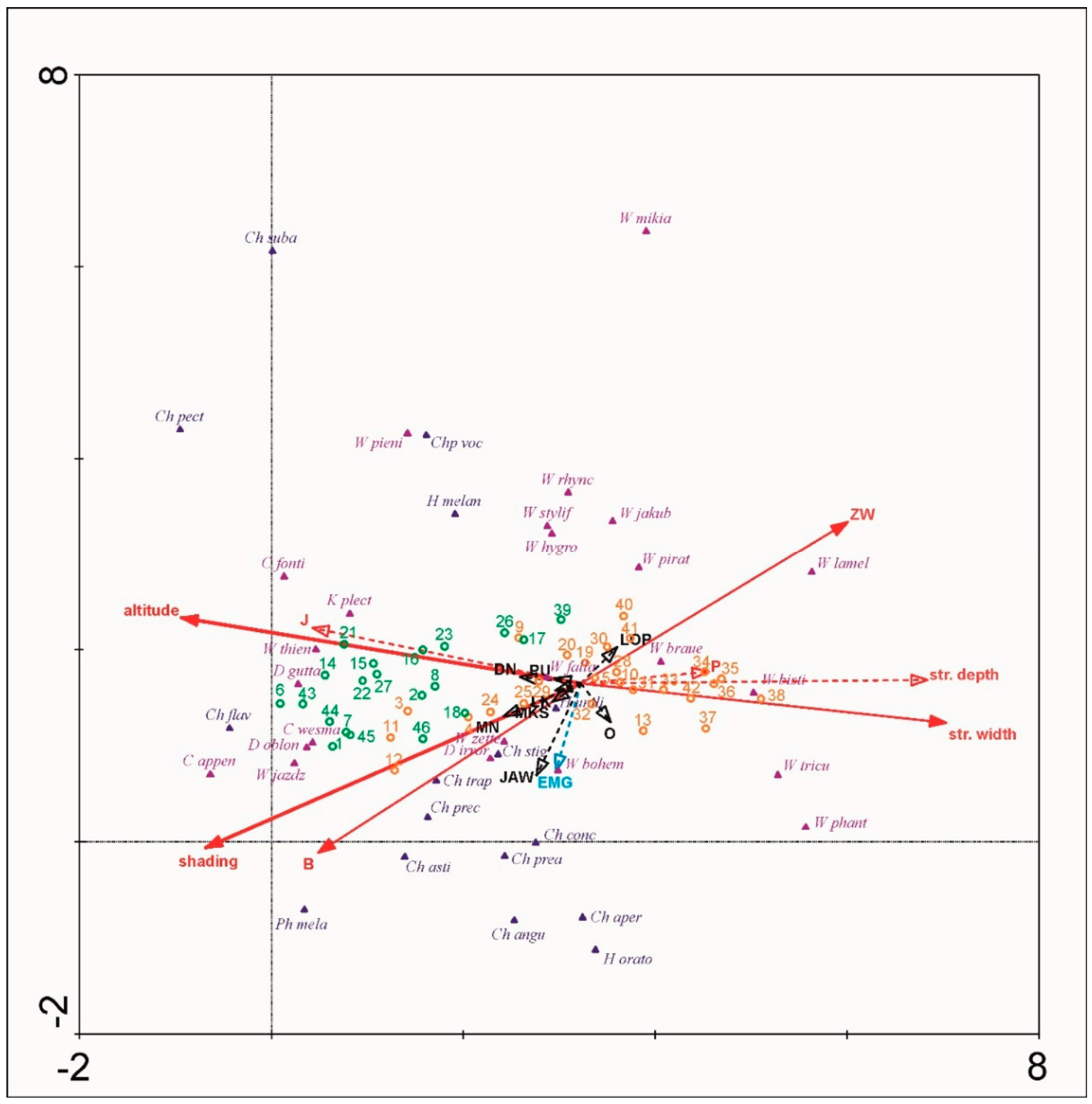

Figure 5. Plot of the detrended canonical correspondence analysis (DCCA) results. Red arrows—environmental variables correlated with 1st DCCA axis, blue arrow - environmental variable correlated with 2nd DCCA axis, black arrowsenvironmental variables not correlated with first two DCCA axes. Canonical correspondence analysis (CCA) results remarked on the DCCA plot: Thick solid arrows-environmental variables significantly explaining biota distribution with CCA $\lambda 1: \lambda 2>1$, thin solid arrows-environmental variables significantly explaining biota distribution with CCA $\lambda 1: \lambda 2<1$, dashed arrows—not significant variables. Sample number remarks: orange—altitude $\leq 550 \mathrm{~m}$; green-altitude $>550 \mathrm{~m}$. Environmental symbols: str. depth—stream mean depth $(\mathrm{cm})$, str. width—stream mean width (cm), B-beech mountain forest, EMG—eutrophic brook flora, J—fir mountain forest, O_alder forest, LOP—burdock brake, MN—rocky grasslands, $\mathrm{P}$-pasture, LK—-meadow, DN—tree plantations, ZW-willow brake, JAW—sycamore mountain forests, MKS—xerothermic grasslands, PU—crop fields. Taxa name abbreviations-Hemerodromiinae (navy blue): Chelifera angusta (Ch angu), C. aperticauda (Ch aper), C. astigma (Ch asti), C. concinnicauda (Ch conc), C. flavella (Ch flav), C. pectinicauda (Ch pect), C. precabunda (Ch prec), C. precatoria (Ch prea), C. stigmatica (Ch stig), C. subangusta (Ch suba), C. trapezina (Ch trap), Chelipoda vocatoria (Chp voc), Hemerodromia melangyna (H melan), H. oratoria (H orato), H. unilineata (H unili), Phyllodromia melanocephala (Ph mela); Clinocerinae (violet): Clinocera appendiculata (C appen), C. fontinalis (C fonti), C. wesmaeli (C wesma), Dolichocephala guttata (D gutta), D. irrorata (D irror), D. oblongoguttata (D oblon), Kowarzia plectrum (K plect), Wiedemannia bistigma (W bisti), W. bohemani (W bohem), W. braueri (W braue), W. fallaciosa (W falla), W. hygrobia (W hygro), W. jakubi (W jakub), W. jazdzezskii (W jazdz), W. lamellata (W lamel), W. mikiana (W mikia), W. phantasma (W phant), W. pieninensis (W pieni), W. pirata (W pirat), W. rhynchops (W rhync), W. stylifera (W stylif), W. thienemanni (W thien), W. tricuspidata (W tricu), W. zetterstedti (W zette). 


\section{Discussion}

\subsection{Species Richness of the Pieniny Mts. vs. Polish and European Mountain Massifs}

The subfamilies Hemerodromiinae and Clinocerinae belong to a large family Empididae, distributed worldwide. They are far more common in temperate localities and mountainous areas. In the present study, 40 species classified in these subfamilies were recorded in the Pieniny Mts. which makes up $62.5 \%$ of Polish fauna [57,58,63,65,67,68,71,72,74,89]. One species, Wiedemannia pieninensis, until recently was known only from the Pieniny Mts., but lately it was recorded in the Tatra Mountains [67]. As a result, currently in the Pieniny Mts., the highest number of aquatic empidids is known compared with other Polish mountain massifs where only 29 species have been noted for the Tatra Mts., 28 for the Gorce Mts., 24 species for both the Bieszczady Mts. and the Babia Mt., and 15 for the Świętokrzyskie Mts. [57,61-63,67,70-72,90,91]. Moreover, significantly lower numbers of aquatic Empididae have been noted also from some much bigger and higher mountain massifs including the Sierra Nevada Mts. in Spain (24 species) [92] or the Caucasus Mts. (31 species) [93-97].

Our study also shows new altitudinal limits for some of the recorded species. One of them is Clinocera appendiculata, which in the Pieniny Mts. was noted at 590-770 m (Table 2; Table 4), which is very surprising because this species is known to occur only in high mountains, e.g., it was found by Vaillant [98] in the French Alps at an altitude up to $2560 \mathrm{~m}$ at the foot of the glacier des Grands Couloirs (north of Pralognan). In the Pieniny Mts., most individuals of this species were found on the boulders covered by moss mats below the spring of the Biały stream $(750 \mathrm{~m})$ located on the northern slopes of this massif [89]. One more interesting species is Chelifera stigmatica which was known only from the Poland headsprings up to $1000 \mathrm{~m}$ [57] while in the present study it was absent in the samples collected in the springs and the upper stream sections. In contrast, it was the most abundant at the foothills below $550 \mathrm{~m}$. Generally for numerous taxa like Chelifera flavella, C. precabunda, C. precatoria, C. trapezina, Phyllodromia melanocephala (Hemerodromiinae) and Clinocera appendiculata, C. wesmaeli, Dolichocephala guttata, D. irrorata, and K. plectrum (Clinocerinae), the highest elevational values of their distribution in the Pieniny Mts. correspond with the lowest elevational values of their distribution observed in other European mountain massifs. Such results clearly suggest significant adaptability of some species of Hemerodromiinae and Clinocerinae to environmental factor changes including habitats and altitude.

\subsection{Elevational Patterns of Hemerodromiinae and Clinocerinae}

The present paper shows the first comprehensive analysis of the elevational distribution of aquatic Empididae in central Europe and it is also one of the few studies focused on this group of Diptera in the world [51-56].

Our study on the distribution of Hemerodromiinae and Clinocerinae along an elevational gradient indicate the richness and abundance decreases with altitude which is rather typical in the elevational distribution of different insect groups including e.g., beetles $[20,29,31,32,34,36]$, butterflies [25,33,35], moths [18,28], or ants [26,27,30]. Comparing the abundance of both subfamilies across eight elevational bands, a clear downwards trend with increasing altitude was apparent. A pronounced reduction in the number of Hemerodromiinae individuals was found from $400-450 \mathrm{~m}$ up, and only 10 individuals were recorded above $750 \mathrm{~m}$. A dramatic decline in the number of individuals with increasing altitude was also revealed for Clinocerinae. For both subfamilies, a distinct species-poor community was recorded at the highest elevation $(>750 \mathrm{~m})$, which also corresponds with numerous other studies focused on mountain insect fauna $[18,20,26-36]$ and usually can be explained by the most extreme environmental conditions observed on the tops of mountain massifs.

Mid-elevation and low elevation peaks in species richness have been observed in different insect groups $[11,17,99]$. Our study data for Hemerodromiinae strongly supported a low elevation peak $(400-450 \mathrm{~m})$ in species richness and monotonic decline in species 
richness with an increase of altitude. In contrast, our findings do not confirm the results of studies on this subfamily at Doi Inthanon, Thailand where the total number of taxa and individuals increased with altitude, declining just above a maximum of $2200 \mathrm{~m}$ [52]. On the other hand, we found that in the Pieniny Mts., the species richness of the subfamily Clinocerinae shows a slightly hump-shaped pattern with a peak of 18 species and the highest values of all diversity indices at a mid-elevational range (551-600 m). Interestingly, consideration of the elevational distribution of singletons and doubletons indicated that rare species contribute to species richness at both low and higher elevation in the Pieniny Mts. Our results for clinocerines corresponds with data received for many other insect groups studied in different mountain areas of the world [13,18-21,23,24], even if a great percentage of these studies were made in much higher mountain massifs than the Pieniny Mts. In contrast to our study, a different trend was found for some other aquatic and terrestrial invertebrate groups studied in Polish mountain massifs including Mount Babia, Tatra Mts., and Bieszczady Mts. as both species richness and number of individuals decreased with increasing altitude [100-105]. In addition, in Doi Inthanon, northern Thailand where the subfamily Empidinae [56] was studied, which is closely related to both empidid subfamilies in our study, a linear increase in abundance and species richness was observed along the elevational gradient. Moreover, Plant et al. [106] noted similar results during a study upon the superfamily Empidoidea in the same area in Asia, as they found that genus richness of Empididae, Hybotidae, and Brachystomatidae increased with elevation, while only for the Dolichopodidae, genus richness was the highest at mid-elevations.

It is assumed that habitat complexity contributes to an increase in species diversity and abundance in many groups of organisms, including aquatic insects [107-110]. Our study shows that species richness and species composition of Hemerodromiinae and Clinocerinae vary along the altitudinal gradient with a peak at the foothills $(<550 \mathrm{~m})$ and decline at the lower montane zone $(>550 \mathrm{~m})$. Data from the foothills shows that the highest number of clinocerines was collected along the Dunajec River valley, which is a major river in the Pieniny Mts., although the species richness was lower than in sites located along smaller streams. Most probably this can be explained by a higher mosaic of microhabitats observed in higher elevations which are more attractive for many aquatic empidid flies. Species with high abundances at lowest elevations, e.g., Wiedemannia bistigma, W. braueri, W. pirata, $W$. stylifera, and $W$. tricuspidata, prefer large streams and medium-sized rivers flowing at altitudes between 400 and 550-600 m. The number of these flies generally decreases with elevation. Moreover, changes in the aquatic empidid fauna along the elevational gradient in the Pieniny Mts. could be due to altitudinal species replacement e.g., Wiedemannia bistigma, $W$. braueri, and W. tricuspidata were restricted mainly to the Dunajec River and Grajcarek stream (both located below $550 \mathrm{~m}$ ) and were replaced by species that prefer the stream valleys (e.g., Clinocera wesmaeli, Kowarzia plectrum, Wiedemannia bohemani, W. jazdzewskii, $W$. thienemanni, and W. zetterstedti). Similar results, where some taxa are restricted to the lower parts of mountain massif and others occur only in its higher regions are commonly noted in different insect groups. Usually, it is explained by different habitat preferences of particular species and is known as one of the standard distributional models [11].

Although different factors affect the occurrence and distribution of insects in a different way, usually, many of them play a role at the same time. In our study, 17 environmental factors were tested, of which only five (also as different combinations) were found to significantly regulate Clinocerinae and Hemerodromiinae distribution at the foothills and the lower montane zone in the Pieniny Mts. Although for some species, lower elevation, less shaded sites and wider streams (or river) with willow vegetation (e.g., Wiedemannia bistigma, W. lamellata, W. phantasma, W. tricuspidata) or higher elevation and heavily shaded sites associated with beech mountain forest (e.g., Chelifera pectinicauda, C. subangusta, Clinocera appendiculata, C. fontinalis, Kowarzia plectrum, Wiedemannia jazdzewskii) were found as the most important factors describing their habitat preferences. For some other aquatic empidids, additional environmental parameters should be studied to clarify their distributional patterns. Such a list can include e.g., stream geomorphology, substratum, 
water current, $\mathrm{pH}$ of water, relative humidity as well as competition between species, as all these factors can play important role in the occurrence and distribution of aquatic immature stages of Clinocerinae and Hemerodromiinae and, as a consequence, also the adult aquatic empidids. Moreover, as we present the first results about habitat preferences for both subfamilies in Europe, future studies focused on aquatic Empididae in other mountain massifs are recommended to verify ecological preferences of particular species not only along elevational but also along a geographical gradient.

Table 4. Altitudinal limits for selected Hemerodromiinae and Clinocerinae species in the European massifs (data from Pieniny Mts. compared with data by Vaillant [98,111-113], Niesiołowski [57] and Palaczyk et al. [71]).

\begin{tabular}{|c|c|c|c|c|c|}
\hline & Alps & Pyrenees & Massif Central & Tatra Mts & Pieniny Mts. \\
\hline \multicolumn{6}{|l|}{ HEMERODROMIINAE } \\
\hline Chelifera astigma & $350-1500$ & & & $970-1100$ & $445-750$ \\
\hline Chelifera flavella & $700-1700$ & & & $970-1500$ & $480-770$ \\
\hline Chelifera pectinicauda & 730 & & 800 & & 770 \\
\hline Chelifera precabunda & $1500-1700$ & & & $910-1520$ & $445-750$ \\
\hline Chelifera precatoria & $700-1100$ & $802-1850$ & 1200 & $930-1000$ & $440-680$ \\
\hline Chelifera stigmatica & 250-1000 & & ca. 1460 & $960-1050$ & $440-680$ \\
\hline Chelifera trapezina & $700-1400$ & $1150-1300$ & & $900-1500$ & $440-770$ \\
\hline Hemerodromia unilineata & $400-1000$ & & 320 & & $440-560$ \\
\hline Hemerodromia oratoria & & & 720 & & $440-445$ \\
\hline Phyllodromia melanocephala & 850-1000 & & & $990-1150$ & $560-640$ \\
\hline \multicolumn{6}{|l|}{ CLINOCERINAE } \\
\hline Clinocera appendiculata & $800-2560$ & $1000-2100$ & & 900-2040 & $590-770$ \\
\hline Clinocera wesmaeli & ca. 1000 & $1000-1300$ & & & $463-770$ \\
\hline Dolichocephala guttata & 2300 & $650-1500$ & & 1100 & $463-750$ \\
\hline Dolichocephala irrorata & & 650 & & $900-1620$ & $440-630$ \\
\hline Kowarzia plectrum & 1900 & & & $980-1150$ & $445-770$ \\
\hline Wiedemannia bistigma & $215-724$ & $115-350$ & $200-470$ & & $415-580$ \\
\hline Wiedemannia bohemani & 215-1000 & 1600 & $700-875$ & 920 & $415-560$ \\
\hline Wiedemannia fallaciosa & $80-1130$ & 1050 & & & $415-610$ \\
\hline Wiedemannia hygrobia & $210-1850$ & $1350-2150$ & & $900-1650$ & $415-640$ \\
\hline Wiedemannia lamellata & & & 386 & & 465 \\
\hline Wiedemannia phantasma & $230-877$ & & & & $420-445$ \\
\hline Wiedemannia zetterstedti & ca. 1000 & & $217-1123$ & & $415-680$ \\
\hline
\end{tabular}

\section{Conclusions}

The results of this study showed that despite the limited altitudinal range of the Pieniny Mts., there are significant changes in relation to aquatic Empididae abundance and species richness along the elevational gradient, which clearly suggests that even in relatively small mountains, significant changes in insect fauna can be correlated with altitude. Obviously, in many aquatic empidids occurring in the Pieniny Mts., the elevational species ranges are much narrower than compared to the Alps, the Pyrenees, or even the Tatra Mts., but it arises from the relatively low altitude of this Polish mountain massif. Moreover, even in such relatively low mountains, the hump-shaped distributional patterns can be characteristic for at least some insect groups. 
Author Contributions: Conceptualization, I.S.; methodology, I.S., R.J.; software, I.S., R.J.; validation, I.S.; formal analysis, I.S., R.J.; investigation, I.S.; resources, I.S.; data curation, I.S.; writing-original draft preparation, I.S., R.J.; writing-review and editing, I.S., R.J.; visualization, I.S., R.J.; supervision, I.S.; project administration, I.S.; funding acquisition, I.S. All authors have read and agreed to the published version of the manuscript.

Funding: This research, including the APC, was partly funded by the statutory funds of the Faculty of Biology and Environmental Protection, University of Lodz.

Acknowledgments: We would like to thank to Mateusz Płóciennik (Łódź) for his venerable help, comments and suggestions according to statistical methods used in this study. The first author would like to thank to Andrzej Szczocarz and Andrzej Sokołowski, the Directors of the Pieniny Mts. National Park, for the permissions needed during field work in the park (no. PB-5132-33/04 and PB-5132-17/08), to Krzysztof Karwowski, Grzegorz Vončina, and Maciej Szajowski for their kind help and hospitality during visits and field work as well as Andrzej Palaczyk (Kraków) who took the picture of Hemerodromia unilineata used in the paper. We would also like to thank to three anonymous reviewers for their comments and suggestions to the first version of manuscript.

Conflicts of Interest: The authors declare no conflict of interest. The funders had no role in the design of the study; in the collection, analyses, or interpretation of data; in the writing of the manuscript, or in the decision to publish the results.

\section{References}

1. Rahbek, C. The elevational gradient of species richness: A uniform pattern? Ecography 1995, 18, 200-205. [CrossRef]

2. Rahbek, C. The relationship among area, elevation, and regional species richness in neotropical birds. Am. Nat. 1997, 149, 875-902. [CrossRef]

3. Terborgh, J. Bird species diversity on an Andean elevational gradient. Ecology 1977, 58, 1007-1019. [CrossRef]

4. Stevens, G.C. The elevational gradient in altitudinal range: An extension of Rapoport's latitudinal rule to altitude. Am. Nat. 1992, 140, 893-911. [CrossRef]

5. Kesller, M. Elevational gradients in species richness and endemism of selected plant groups in the central Bolivian Andes. Plant Ecol. 2000, 149, 181-193. [CrossRef]

6. Jones, J.I.; Li, W.; Marbely, S. Area, altitude and Aquatic plant diversity. Ecography 2003, 26, 411-420. [CrossRef]

7. Mallet-Rodrigues, F.; Parrini, R.; Pimentel, L.M.S.; Bessa, R. Altitudinal distribution of birds in a mountainous region in southeastern Brazil. Zoologia 2010, 27, 503-522. [CrossRef]

8. Bhatt, D.; Joshi, K.K. Bird assemblages in natural and urbanized habitats along elevational gradient in Nainital district (western Himalaya) of Uttarakhand state, India. Curr. Zool. 2011, 57, 318-329. [CrossRef]

9. Hu, Y.; Jin, K.; Huang, Z.; Ding, Z.; Liang, J.; Pan, X.; Hu, H.; Jiang, Z. Elevational patterns of non-volant small mammal species richness in Gyirong Valley, Central Himalaya: Evaluating multiple spatial and environmental drivers. J. Biogeogr. 2017, 44, $2764-2777$. [CrossRef]

10. Gebrehiwot, K.; Demissew, S.; Woldu, Z.; Fekadu, M.; Desalegn, T.; Teferi, E. Elevational changes in vascular plants richness, diversity, and distribution pattern in Abune Yosef mountain range, Northern Ethiopia. Plant Divers. 2019, 41, 220-228. [CrossRef]

11. McCoy, E.D. The distribution of insects along elevational gradients. Oikos 1990, 58, 313-332. [CrossRef]

12. Colwell, R.K.; Hurtt, G.C. Nonbiological gradients in species richness and a spurious Rapoport effect. Am. Nat. 1994, 144, 570-595. [CrossRef]

13. Olson, D.M. The distribution of leaf litter invertebrates along a Neotropical altitudinal gradient. J. Trop. Ecol. 1994, 10, 129-150. [CrossRef]

14. Colwell, R.K.; Less, D.C. The mid-domain effect: Geometric constraints on the geography of species richness. Trends Ecol. Evol. 2000, 15, 70-76. [CrossRef]

15. Colwell, R.K.; Rahbek, C.; Gotelli, N.J. The mid-domain effect and species richness patterns: What have we learned so far? Am. Nat. 2004, 163, E1-E23. [CrossRef] [PubMed]

16. Colwell, R.K.; Rahbek, C.; Gotelli, N.J. The mid-domain effect: There's a baby in the bathwater. Am. Nat. 2005, 166, E149-E154. [CrossRef]

17. Rahbek, C. The role of spatial scale and the perception of large-scale species richness patterns. Ecol. Lett. 2005, 8, 224-239. [CrossRef]

18. Brehm, G.; Colwell, R.K.; Kluge, J. The role of environment and mid-domain effect on moth species richness along a tropical elevational gradient. Glob. Ecol. Biogeogr. 2007, 16, 205-219. [CrossRef]

19. Choi, S.W.; Am, J.S. Altitudinal distribution of moths (Lepidoptera) in Mt. Jirisan National Park, South Korea. Eur. J. Entomol. 2010, 107, 229-245. [CrossRef] 
20. Herzog, S.K.; Hamel-Leigue, A.C.; Larsen, T.H.; Mann, D.J.; Soria-Auza, R.W.; Gill, B.D.; Edmonds, W.D.; Spector, S. Elevational Distribution and Conservation Biogeography of Phanaeine Dung Beetles (Coleoptera: Scarabaeinae) in Bolivia. PLoS ONE 2013, 8, e64963. [CrossRef]

21. Le Cesne, M.; Wilson, S.W.; Soulier-Perkins, A. Elevational gradient of Hemiptera (Heteroptera, Auchenorrhyncha) on a tropicalmountain in Papua New Guinea. PeerJ 2015, 3, e978. [CrossRef] [PubMed]

22. Widhiono, I.; Sudiana, E.; Darsono, D. Diversity of wild bees along elevational gradient in an agricultural area in central Java, Indonesia. Psyche A J. Entomol. 2017, 2017, 2968414. [CrossRef]

23. Longino, J.T.; Branstetter, M.G. The truncated bell: An enigmatic but pervasive elevational diversity pattern in Middle American ants. Ecography 2018, 41, 1-12. [CrossRef]

24. Subedi, I.P.; Budha, P.B. Diversity and distribution patterns of ants along elevational gradients. Nepal. J. Zool. 2020, 4, 44-49. [CrossRef]

25. Sanchez-Rodriguez, J.F.; Baz, A. The effects of elevation on the butterfly communities of a Mediterranean mountain, Sierra de Javalambre, central Spain. J. Lepid. Soc. 1995, 49, 192-207.

26. Sanders, N.J. Elevational gradients in ant species richness: Area, geometry, and Rapoport's rule. Ecography 2002, 25, 25-32. [CrossRef]

27. Sanders, N.J.; Moss, J.; Wagner, D. Patterns of ant species richness along elevational gradients in an arid ecosystem. Glob. Ecol. Biogeogr. 2003, 12, 93-102. [CrossRef]

28. Beck, J.; Altermatt, F.; Hagmann, R.; Lang, S. Seasonality in the altitude-diversity pattern of Alpine moths. Basic Appl. Ecol. 2010, 11, 714-722. [CrossRef]

29. Maveety, S.A.; Browne, R.A.; Erwin, T.L. Carabidae diversity along an altitudinal gradient in a Peruvian cloud forest (Coleoptera). ZooKeys 2011, 147, 651-666. [CrossRef]

30. Bharti, H.; Dharma, Y.P.; Bharti, M.; Pfeiffer, M. Ant species richness, endemicity and functional groups, along an elevational gradient in the Himalayas. Asian Myrmecol. 2013, 5, 79-101.

31. Yu, X.-D.; Lü, L.; Luo, T.-H.; Zhou, H.-Z. Elevational Gradient in Species Richness Pattern of Epigaeic Beetles and Underlying Mechanisms at East Slope of Balang Mountain in Southwestern China. PLoS ONE 2013, 8, e69177. [CrossRef] [PubMed]

32. Pizzolotto, R.; Gobbi, M.; Brandmayr, P. Changes in ground beetle assemblages above and below the treeline of the Dolomites after almost 30 years (1980/2009). Ecol. Evol. 2014, 4, 1284-1294. [CrossRef] [PubMed]

33. Sánchez-Reyes, U.J.; Niño-Maldonado, S.; Jones, R.W. Diversity and altitudinal distribution of Chrysomelidae (Coleoptera) in Peregrina Canyon, Tamaulipas, Mexico. ZooKeys 2014, 417, 103-132.

34. Pizzolotto, R.; Albertini, A.; Gobbi, M.; Brandmayr, P. Habitat diversity analysis along an altitudinal sequence of alpine habitats: The Carabid beetle assemblages as a study model. Period. Biol. 2016, 118, 241-254. [CrossRef]

35. Scalercio, S.; Bonacci, T.; Mazzei, A.; Pizzolotto, R.; Brandmayr, P. Better up, worse down: Bidirectional consequences of three decades of climate change on a relict population of Erebia cassioides. J. Insect Conserv. 2014, 18, 643-650. [CrossRef]

36. Chamberlain, D.; Gobbi, M.; Negro, M.; Caprio, E.; Palestrini, C.; Pedrotti, L.; Brandmayr, P.; Pizzolotto, R.; Rolando, A. Traitmodulated decline of carabid beetle occurrence along elevational gradients across the European Alps. J. Biogeogr. 2020, 47, 1030-1040. [CrossRef]

37. Baz, A.; Cifrián, B.; María Díaz-Aranda, L.; Martín-Vega, M. The distribution of adult blow-flies (Diptera: Calliphoridae) along an altitudinal gradient in Central Spain. Ann. Soc. Entomol. Fr. 2007, 43, 289-296. [CrossRef]

38. Hackenberger, B.K.; Jarić, D.; Krčmar, S. Distribution of Tabanids (Diptera: Tabanidae) Along a Two-Sided Altitudinal Transect. Environ. Entomol. 2009, 38, 1600-1607. [CrossRef]

39. Lambkin, C.L.; Boulter, S.L.; Starick, N.T.; Cantrell, B.K.; Bickel, D.J.; Wright, S.G.; Power, N.; Schutze, M.K.; Turco, F.; Nakamura, A.; et al. Altitudinal and seasonal variation in the family-level assemblages of flies (Diptera) in Australian subtropical rainforest: One hundred thousand and counting! Mem. Qld. Mus. Nat. 2011, 55, 315-331.

40. Mujica, N.; Kroschel, J.; Zebitz, C. Latitudinal and altitudinal distribution and relative importance of the leafminer flies Liriomyza huidobrensis and L. sativae (Diptera: Agromyzidae) in low and highland regions of Peru. Mitt. Dtsch. Ges. Allg. Angew. Entomol. 2012, 18, 297-300.

41. Rohner, P.T.; Bächli, G.; Pollini Paltrinieri, L.; Duelli, P.; Obrist, M.K.; Jochmann, R.; Blanckenhorn, W.U. Distribution, diversity gradients and Rapoport's elevational rule in the black scavenger flies of the Swiss Alps (Diptera: Sepsidae). Insect Conserv. Divers. 2015, 8, 367-376. [CrossRef]

42. Sengupta, J.; Naskar, A.; Maity, A.; Banerjee, D. Effects of selected environmental variable upon the distribution of hover fly (Insecta: Diptera: Syrphidae) along with an altitudinal gradient. Int. J. Adv. Life Sci. Res. 2018, 1, 1-6. [CrossRef]

43. Lamontagne, S.; Donald, D.B.; Schindler, D.W. The distribution of four Chaohorus species (Diptera: Chaoboridae) along an elevation gradient in Canadian Rocky Mountain lakes. Can. J. Zool. 1994, 72, 1531-1537. [CrossRef]

44. Denke, P.M.; Lloyd, J.E.; Littlefield, J.L. Elevational distribution of mosquitoes in a mountainous area of southeastern Wyoming. J. Am. Mosq. Control Assoc. 1996, 12, 8-16.

45. Frutiger, A.; Gammeter, S. Faunistics and altitudinal distribution of net-winged midges (Diptera: Blephariceridae) in Switzerland and Liechtenstein. Mitteilungen der Schweizerischen Entomologischen Gesellschaft. Bull. Soc. Entomol. Suisse 1998, 71, 115-124.

46. Scheibler, E.E.; Roig-Juñent, S.A.; Claps, M.C. Chironomid (Insecta: Diptera) assemblages along an Andean altitudinal gradient. Aquat. Biol. 2014, 20, 169-184. [CrossRef] 
47. Matthews-Bird, F.; Gosling, W.D.; Coe, A.L.; Bush, M.; Mayle, F.E.; Axford, Y.; Brooks, S.J. Environmental controls on the distribution and diversity of lentic Chironomidae (Insecta: Diptera) across an altitudinal gradient in tropical South America. Ecol. Evol. 2016, 6, 91-112. [CrossRef]

48. Mantilla, J.S.; Moncada, L.I.; Matta, N.E.; Adler, P.H. Distribution of black flies (Diptera: Simuliidae) along an elevational gradient in the Andes Mountains of Colombia during the El Niño Southern Oscillation. Acta Trop. 2018, 183, 162-172. [CrossRef]

49. Khairul Husna, N.; Noor Nasuha, A.A.; Saiyid Jalaluddin, S.S.; Muhammad Luqman Hakim, A.; Nurul Fatihah, A.L.; Idris, A.B.; Siti Khairiyah, M.H. Diversity and abundance of dipteran species at two different elevations in Gunung Datuk, Negeri Sembilan, Malaysia. Serangga 2018, 23, 194-202.

50. Ivković, M.; Plant, A. Aquatic insects in the Dinarides: Identifying hotspots of endemism and species richness shaped by geological and hydrological history using Empididae (Diptera). Insect Conserv. Divers. 2015, 8, 302-312. [CrossRef]

51. Plant, A.R. Diversity of Chelipoda Macquart, 1823 (Diptera: Empididae: Hemerodromiinae) in northern Thailand with discussion of a biodiversity 'hotspot' at Doi Inthanon. Raffles Bull. Zool. 2009, 57, 255-277.

52. Plant, A.R.; Surin, C.; Saokhod, R.; Srisuka, W. Elevational Gradients of Diversity and Species Composition of Hemerodromiinae (Diptera: Empididae) at Doi Inthanon, Thailand: Has Historical Partitioning between Seasonally Dry Lowland and Aseasonal Moist Mountain Forests Contributed to the Biodiversity of Southeast Asia? Trop. Nat. Hist. 2012, 12, 9-20.

53. Plant, A.R.; Bickel, D.J.; Chatelain, P.; Hauser, M.; Le Cesne, M.; Surin, C.; Saokhod, R.; Nama, S.; Soulier-Perkins, A.; Daugeron, C.; et al. Spatiotemporal dynamics of insect diversity in tropical seasonal forests is linked to season and elevation, a case from northern Thailand. Raffles Bull. Zool. 2018, 66, 382-393.

54. Plant, A.R.; Bickel, D.J.; Chatelain, P.; Daugeron, C.; Srisuka, W. Composition and organization of highly speciose Empidoidea (Diptera) communities in tropical montane forests of northern Thailand. Zootaxa 2019, 4590, 1-39. [CrossRef]

55. Plant, A.R.; Bickel, D.J.; Chatelain, P.; Daugeron, C.; Srisuka, W. Endemism, Similarity and Difference in Montane Evergreen Forest Biodiversity Hotspots: Comparing Communities of Empidoidea (Insecta: Diptera) in the Summit Zones of Doi Inthanon and Doi Phahompok, Thailand. Trop. Nat. Hist. 2020, 20, 16-27.

56. Chatelain, P.; Plant, A.; Soulier, A.; Daugeron, C. Diversity increases with elevation: Empidine dance flies (Diptera, Empididae) challenge a predominant pattern. Biotropica 2018, 50, 633-640. [CrossRef]

57. Niesiołowski, S. Morfologia, Biologia i Występowanie w Polsce Wodnych Empididae (Diptera, Brachycera); Acta Universitatis Lodzensis, Folia limnologica: Łódź, Polska, 1990; pp. 1-169.

58. Krysiak, I.; Niesiołowski, S. Wiedemannia pieninensis a New Species of Aquatic Empidid (Diptera, Empididae) from Poland. Aquat. Insects 2004, 26, 143-146. [CrossRef]

59. Krysiak, I. Wiedemannia jakubi a New Species of Aquatic Empidid (Diptera: Empididae) from Poland. Ann. Zool. 2005, 55, 75-76.

60. Krysiak, I.; Palaczyk, A.; Wanat, D. Empidoidea (Diptera: Brachycera). In Owady (Insecta) Parku Krajobrazowego Wzniesień Łódzkich; Jaskuła, R., Tończyk, G., Eds.; Dyrekcja Parku Krajobrazowego Wzniesień Łódzkich/Mazowiecko-Świętokrzyskie Towarzystwo Ornitologiczne: Łódź, Polska, 2010; pp. 159-163.

61. Słowińska-Krysiak, I. New Records of an Extremely Rare Aquatic Empidid Fly Chelifera polonica Wagner and Niesiolowski, 1987 (Diptera: Empididae: Hemerodromiinae) from Poland. J. Entomol. Res. Soc. 2012, 14, 99-103.

62. Słowińska-Krysiak, I. Chelifera pectinicauda COLLIN, 1927 i Chelifera subangusta COLLIN, 1961—nowe dla Bieszczadów gatunki Hemerodromiinae (Diptera: Empididae). Wiad. Entomol. 2013, 32, 147-150.

63. Słowińska-Krysiak, I. New Distributional Data for the Rare Polish Empidid Flies (Empididae: Hemerodromiinae, Clinocerinae) in the Pieniny Mountains with Notes on Ecology and Phenology. J. Entomol. Res. Soc. 2014, 16, 127-140.

64. Słowińska-Krysiak, I. Nowe stanowisko Wiedemannia pieninensis Krysiak et Niesiołowski, 2004 (Empididae: Clinocerinae) w Pieninach. Pienininy Przyroda i Człowiek 2014, 13, 63-65.

65. Słowińska, I. New records of the rare species Chelifera aperticauda Collin, 1927 (Diptera: Empididae: Hemerodromiinae) from Poland. Dipteron 2017, 33, 121-126.

66. Słowińska, I. Hemerodromiinae i Clinocerinae (Diptera: Empididae) Małych Pienin. Dipteron 2017, 33, $143-156$.

67. Słowińska, I. First record of the rare species Wiedemannia pieninensis Krysiak et Niesiołowski, 2004 (Diptera: Empididae: Clinocerinae) from the Polish Tatra Mountains. Dipteron 2019, 35, 178-184.

68. Palaczyk, A.; Słowińska-Krysiak, I. The genus Phaeobalia Mik, 1881 in Poland (Diptera: Empididae: Clinocerinae). Genus 2013, $24,415-424$.

69. Słowińska-Krysiak, I.; Palaczyk, A. Empidoidea (Diptera: Brachycera) Spalskiego Parku Krajobrazowego. Dipteron $2014,30,63-75$.

70. Słowińska, I.; Palaczyk, A. Nowe dane o Hemerodromiinae (Diptera: Empididae) Tatr polskich. Dipteron 2015, $31,37-49$.

71. Palaczyk, A.; Słowińska, I.; Klasa, A. The Genus Bergenstammia Mik, 1881 (Diptera: Empididae: Clinocerinae) in Poland with Description of Bergenstammia glacialis sp. nov. from the Tatra Mts. Ann. Zool. 2015, 65, 53-64. [CrossRef]

72. Słowińska, I.; Palaczyk, A. Hemerodromiinae (Diptera: Empididae) Gorców. Dipteron 2016, 32, 67-76.

73. Oboňa, J.; Baranová, B.; Hrivniak, L.; Kisková, K.; Manko, P.; Słowińska, I. First record of the rare aquatic dance fly Chelifera aperticauda Collin, 1927 (Diptera: Empididae: Hemerodromiinae) from Slovakia. Check List 2016, 12, 1894. [CrossRef]

74. Słowińska, I.; Zawal, A.; Stryjecki, R.; Michoński, G. First detailed records of water mite larvae (Hydrachnidia: Hydrovolzidae, Hydryphantidae) parasitizing empidid flies (Diptera: Empididae: Clinocerinae). Int. J. Parasitol. Parasites Wildl. 2020, 12, 165-171. [CrossRef] [PubMed] 
75. Ivković, M.; Čorkalo, M.; Tkoč, M. Aquatic dance flies of Czech Republic (Empididae: Clinocerinae and Hemerodromiinae): New records and updated species list. Zootaxa 2020, 4790, 76-90. [CrossRef] [PubMed]

76. Kondracki, J. Geografia Regionalna Polski; PWN: Warszawa, Poland, 2000; pp. 1-441.

77. Nyka, J. Pieniny. Przewodnik. In Wydawnictwo Trawers; Wyd. VIII: Latchorzew, Poland, 2000; 304p.

78. Birkenmajer, K. Aktualne problemy geologiczne Pienin. Pienininy Przyroda i Człowiek 2003, 8, 33-40.

79. Birkenmajer, K. Geology of the Pieniny Mountains, West Carpathians, Poland. Monogr. Pienin. Mt. 2017, 3, 5-66.

80. Biesiadka, E. Wodopójki (Hydracarina) Pienin. Fragm. Faun. 1979, 24, 97-173. [CrossRef]

81. Niemirowski, M. Zarys fizjografii Pienin. Położenie i ukształtowanie. In Przyroda Pienin w Obliczu Zmian. Studia Naturae Seria B; Zarzycki, K., Ed.; Państwowe Wydawnictwo Naukowe: Warszawa-Kraków, Poland, 1982; Volume 30, pp. 17-31.

82. Kostrakiewicz, L. Hydrografia. In Przyroda Pienin w Obliczu Zmian. Studia Naturae Seria B; Zarzycki, K., Ed.; Państwowe Wydawnictwo Naukowe: Warszawa-Kraków, Poland, 1982; Volume 30, pp. 70-93.

83. Biesiadka, E. Ogólna charakterystyka faunistyczna środowisk wodnych Pienin. Fragm. Faun. 1979, 24, 283-293. [CrossRef]

84. Małecka, D.; Humnicki, W. Problemy hydrogeologii i ochrony wód Pienińskiego Parku Narodowego. Pieniny Przyroda iCzłowiek 2002, 7, 49-70.

85. Witkowski, Z. Fauna Pienińskiego Parku Narodowego, jej zagrożenie i ochrona. Pienininy Przyrida i Człowiek 2003, 8, 71-82.

86. Razowski, J. Charakterystyka flory i fauny Pienin. In Flora i Fauna Pienin. Monografie Pienińskie; Razowski, J., Ed.; Pieniński Park Narodowy: Krościenko nad Dunajcem, Poland, 2000; Volume 1, pp. 11-21.

87. Clark, K.R.; Gorley, R.N. PRIMER v5: User Manual/Tutorial; PRIMER-E: Plymouth, UK, 2001.

88. Ter Braak, C.J.F.; Šmilauer, P. CANOCO Reference Manual and CanoDraw for Windows User's Guide: Software for Canonical Community Ordination, Version-4.5; Microcomputer Power: Ithaca, NY, USA, 2002.

89. Krysiak, I. Muchówki z Podrodzin Hemerodromiinae i Clinocerinae (Diptera, Empididae) Pienin. [Hemerodromiinae and Clinocerinae (Diptera, Empididae) of Pieniny Mountains]. Ph.D. Thesis, University of Łódź, Łódź, Poland, 2005.

90. Klasa, A.; Palaczyk, A.; Soszyński, B. Muchówki (Diptera) Bieszczadów. Monografie Bieszczadzkie 2000, 8, 305-369.

91. Palaczyk, A.; Klasa, A. Muchówki (Diptera) masywu Babiej Góry. In Monografia Fauny Babiej Góry; Wołoszyn, B.W., Wołoszyn, D., Celary, W., Eds.; Komitet Ochrony Przyrody Polskiej Akademii Nauk: Kraków, Poland, 2003; pp. 305-357.

92. Ivković, M.; Zamora-Muñoz, C.; Sainz-Bariaín, M.; Sinclair, B.J. Aquatic Empididae (Diptera: Hemerodromiinae and Clinocerinae) of the Sierra Nevada, Spain, with the description of five new species. Zootaxa 2014, 3786, 541-556. [CrossRef]

93. Joost, W. Hemerodromia illiesi sp. n. aus Georgien (UdSSR) (Diptera, Empididae). Reichenbachia 1980, 18, 81-83.

94. Joost, W. Beitrag zur Kenntnis der Hemerodromiinae des Kaukasus (I) (Diptera, Empididae). Reichenbachia 1981, $19,183-191$.

95. Joost, W. Dolichocepahala monae sp. n. aus Armenien (UdSSR) (Diptera, Empididae). Reichenbachia 1981, 19, $193-195$.

96. Sinclair, B.J.; Shamshev, I.V. Review of Clinocerinae (Diptera: Empididae) from the Caucasus, with description of three new species. Proc. Zool. Inst. Ras 2014, 318, 40-47.

97. Kustov, S.; Zherebilo, D. New data on the genus Wiedemannia Zetterstedt (Diptera: Empididae) from the Caucasus with description of four new species. Zootaxa 2015, 4032, 351-369. [CrossRef]

98. Vaillant, F. Quelques Insectes Diptères, à larves aquatiques, du Parc de la Vanoise. Trav. Sci. Parc. Natl. Vanoise 1973, 3, $133-165$.

99. Wolda, H. Altitude, habitat and tropical insect diversity. Biol. J. Linn. Soc. 1987, 30, 313-323. [CrossRef]

100. Pawłowski, J. Chrzaszcze (Coleoptera) Babiej Góry. Acta Zool. Crac. 1967, 2, 419-665.

101. Mielewczyk, S. Ważki (Odonata) Pienin. Fragm. Faun. 1978, 22, 265-294.

102. Mielewczyk, S. Pluskwiaki wodne (Heteroptera aquatica et semiaquatica) Pienin. Fragm. Faun. 1978, 22, $295-336$.

103. Dyduch-Falniowska, A. The Gastropods of the Polish Tatra Mountains; Zakład Ochrony Przyrody i Zasobów Naturalnych PAN: Kraków, Poland, 1991; pp. 1-111.

104. Szczęsny, B.; Wiśniowska, A. Fauna jętek (Ephemeroptera) Babiej Góry. In Monografia Fauny Babiej Góry; Wołoszyn, B.W., Wołoszyn, D., Celary, W., Eds.; Komitet Ochrony Przyrody Polskiej Akademii Nauk: Kraków, Poland, $2003 ;$ pp. $123-139$.

105. Szczęsny, B.; Wiśniowska, A. Fauna widelnic (Plecoptera) Babiej Góry. In Monografia Fauny Babiej Góry; Wołoszyn, B.W., Wołoszyn, D., Celary, W., Eds.; Komitet Ochrony Przyrody Polskiej Akademii Nauk: Kraków, Poland, 2003; pp. 141-158.

106. Plant, A.R. Diversity, distribution and community composition of Empididae, Hybotidae and Brachystomatidae (Insecta: Diptera) in Thailand-How did they arise? Res. Knowl. 2015, 1, 1-14.

107. MacArthur, R.H. Environmental factors affecting bird species diversity. Am. Nat. 1964, 98, 387-397.

108. MacArthur, R.H. Patterns of species diversity. Biol. Rev. 1965, 40, 510-533. [CrossRef]

109. Rosenzweig, M.L.; Winakur, J. Population ecology of desert rodent communities: Habitats and environmental complexity. Ecology 1969, 50, 558-572. [CrossRef]

110. Allan, D.J. The distributional ecology and diversity of benthic insects in Cement Creek, Colorado. Ecology 1975, 56, 1040-1053. [CrossRef]

111. Vaillant, F. La répartition des Wiedemannia dans les cours d'eau et leur utilisation comme inidicateurs de zones écologiques (Diptera, Empididae). Ann. Limnol. 1967, 3, 267-293. [CrossRef]

112. Vaillant, F. Quelques Empididae Hemerodromiinae des Pyrénées (Diptera). Ann. Limnol. 1968, 4, 85-93. [CrossRef]

113. Vaillant, F. Diptères Empididae Hemerodromiinae nouveaux ou peu connus de la région paléartique (première partie). Bonn. Zool. Beiträge 1981, 32, 351-408. 